\title{
Aquifoliaceae no Estado do Paraná, Brasil
}

\author{
(D) Marcelo Leandro Brotto ${ }^{1,2}$
}

\begin{abstract}
Como citar: Brotto, M.L. 2021. Aquifoliaceae no Estado do Paraná, Brasil. Hoehnea 49: e072021. https://doi. org/10.1590/2236-8906-07/2021
\end{abstract}

\begin{abstract}
Aquifoliaceae in the Paraná State, Brazil). The Aquifoliaceae family has notable structural and floristic importance in the forests of Paraná state. Ilex is its only genus and possesses several taxa with large morphological range, which complicates the species identification. The main aim of the present study was to recognize the species and varieties of Aquifoliaceae in the state of Paraná, in addition to perform an identification key, descriptions, illustrations, information on geographic distribution, and phenophases. Were analyzed collections from 30 national and international herbaria. Our results show that the genus Ilex is represented by 12 species and two varieties in Paraná. The Dense Ombrophylous Forest and the Araucaria Forest exhibit the highest frequency of records and highest number of species. The morphology of the leaves and inflorescences is a major character for taxa identification. It is proposed a status novus for Ilex theezans var. gracilior (Warmg.) Loes.
\end{abstract}

Keywords: Atlantic Rainforest, Cerrado, erva mate, Flora of Paraná, Taxonomy

RESUMO - (Aquifoliaceae no Estado do Paraná, Brasil). A família Aquifoliaceae tem grande importância estrutural e florística nas florestas do Estado do Paraná. Ilex é seu único gênero e possui vários táxons com amplitude morfológica acentuada, o que dificulta o trabalho de identificação. O objetivo principal do presente estudo foi reconhecer as espécies e variedades de Aquifoliaceae existentes no Estado, além de produzir chave de identificação, descrições, ilustrações, informações sobre distribuição geográfica e fenofases. Foram analisadas coleções de 30 herbários nacionais e internacionais. Os resultados mostram que o gênero Ilex é representado por doze espécies e duas variedades no Paraná. As Florestas Ombrófilas Densa e Mista apresentam maior frequência de registros e maior número de espécies. A morfologia das folhas e inflorescências é preponderante para a identificação dos táxons. Um status novus é proposto para Ilex theezans var. gracilior (Warmg.) Loes. Palavras-chave: Cerrado, erva mate, Flora do Paraná, Mata Atlântica, Taxonomia

\section{Introdução}

A família Aquifoliaceae Bercht. \& J. Presl é composta por cerca de 600 espécies pertencentes ao gênero monotípico Ilex L. Sua distribuição se dá nas regiões tropicais e temperadas do planeta, nas quais o leste Asiático e a América do Sul são seus centros de diversidade. O gênero é composto por árvores e arbustos que ocorrem nas mais variadas formações (Manen et al. 2010, Loizeau et al. 2016, Yao et al. 2016). O Brasil possui 58 espécies, em sua maioria concentradas nas regiões Nordeste e Sudeste, com 29 presentes no bioma Mata Atlântica e 28 no Cerrado (Groppo 2015).

Ilex reúne 12 espécies nas Florestas Ombrófilas do Leste do Brasil e é um dos gêneros com maior número de espécies e de indivíduos na Floresta Ombrófila Densa e na Floresta Ombrófila Mista do Estado do Paraná, com destaque para Ilex microdonta Reissek que é dominante na mata nebular da Serra do Mar (Koehler et al. 2002, Scheer et al. 2011, Scheer \& Blum 2011, Vieira et al. 2014, Groppo 2015). Outras espécies são relevantes na composição das florestas sobre solos de melhor drenagem na Planície Litorânea (Ziller et al. 1999), ou então no estrato inferior da Floresta Ombrófila
Densa da Serra do Mar e ainda no estrado médio da Floresta Ombrófila Mista, onde Ilex paraguariensis A.St.-Hil.. é uma das mais comuns (Roderjan et al. 2002).

Ilex paraguariensis é conhecida popularmente como erva mate, que é a matéria prima utilizada na produção de bebidas tônicas e estimulantes como o chá mate e o chimarrão (bebida tradicional do Cone Sul). As outras espécies do gênero, por sua vez, já tiveram grande importância na indústria da madeira no sul do Brasil fornecendo matéria prima para fabricação de caixotaria, além de serem usadas como lenha (Edwin \& Reitz 1967). Contudo, a única delas que mantém a relevância econômica na região é Ilex paraguariensis (IBGE 2020a). As outras perderam importância econômica no fornecimento de madeira na medida em que foram sendo introduzidas essências exóticas para esse fim, como Pinus e Eucalyptus, e também por causa das restrições à exploração dos remanescentes florestais impostas pela Lei da Mata Atlântica (Lei n 11.428/2006).

Ilex paraguariensis foi descrita a partir de amostras coletadas no Estado do Paraná por Auguste de Saint-Hilaire apesar do seu nome fazer referência ao país vizinho. Na época, a erva de origem paraguaia era de melhor qualidade quando

1. Museu Botânico Municipal de Curitiba, Prefeitura Municipal de Curitiba, Rua Engenheiro Ostoja Roguski, 690, Jardim Botânico, 80210-390, Curitiba, PR, Brasil

2. Autor para correspondência: mabrotto@curitiba.pr.gov.br 
comparada àquela que era produzida no Brasil devido a diferenças no processo de beneficiamento (Saint-Hilaire 1823). Ao que tudo indica, essa foi a motivação para a escolha do nome que foi publicado ainda durante a viagem de SaintHilaire através do Brasil, Uruguai e Argentina. Além dele, outros naturalistas como Schwacke, Sellow e Weir também cruzaram o Estado do Paraná em meados do século XIX colecionando diversas amostras de Aquifoliaceae. Suas coleções foram fundamentais para a descrição de novos táxons na Flora Brasiliensis (Reissek 1861) e na Monografia Aquifoliacearum (Loesener 1901).

Atualmente são reconhecidas doze espécies nativas de Ilex para a região Sul e onze para o Estado do Paraná (Groppo 2014, 2015). Mas, apesar de sua importância a família só recebeu um tratamento taxonômico específico para o Estado mais de cem anos depois das opera princeps. Um deles foi realizado na Serra de Araçatuba (Brotto et al. 2007) e outro na bacia do rio Tibagi (Viani \& Vieira 2007), ambos com seis espécies citadas. Mesmo com esses estudos e com a lista de espécies já publicada para o Estado (Groppo 2014), ainda se faz necessária uma referência que permita o rápido reconhecimento dos táxons e que os relacione com as suas diversas fitofisionomias. Uma grande dificuldade se refere ao elevado número de espécies, variedades e formas reconhecidas por Loesener (1901) que somada à plasticidade morfológica das folhas torna muito difícil a identificação de alguns táxons (Groppo \& Pirani 2002, 2005). Portanto, o presente estudo tem como objetivos reconhecer todas as espécies de Ilex existentes no Paraná, produzir uma chave de identificação, descrições, ilustrações, e ainda apresentar informações sobre distribuição geográfica e fenofases.

\section{Material e métodos}

O Estado do Paraná está situado na região Sul do Brasil, entre as coordenadas $22^{\circ} 29^{\prime} 30^{\prime \prime}-26^{\circ} 41^{\prime} 00^{\prime \prime} \mathrm{S}$ e 4802'24'-54³7’38' W, possuindo área de $199.305 \mathrm{~km}^{2}$, o que representa $2,5 \%$ da superfície total do país (IBGE 2020b). Ele pode ser segmentado em cinco grandes unidades geográficas, de Leste para Oeste: Planície Litorânea, Serra do Mar, Primeiro Planalto, Segundo Planalto e Terceiro Planalto (Maack 2002). Sobre o Estado atuam quatro tipos climáticos segundo a classificação de Köppen, predominando os climas subtropicais Cfa e $\mathrm{Cfb}$ que atuam em $61,7 \%$ e 37,0\% de sua superfície, respectivamente, enquanto que os climas tropicais Aw e Am atuam em 0,8\% e 0,4\%, respectivamente (Alvares et al. 2013). Sua cobertura vegetal está dividida em cinco grandes unidades fitogeográficas: Floresta Ombrófila Densa (FOD), Floresta Ombrófila Mista (FOM), Floresta Estacional Semidecidual (FES), Savana e Estepe, além das Formações Pioneiras e Refúgios Vegetacionais (Roderjan et al. 2002).

Foram analisadas as coleções de Aquifoliaceae (2616 exsicatas) depositadas nos herbários ALCB, B, BR, CEPEC, CESJ, DVPR, EFC*, ESA, FLOR, FURB, FUEL*, HCF*, HFC* $^{*}, \mathrm{HUCP}^{*}$, HUEFS, HUEM* ${ }^{*} \mathrm{HUPG}^{*}, \mathrm{~K}, \mathrm{MBM}^{*}, \mathrm{NY}$, P, RB, S, SP, SPF, SPSF, UEC, UNOP, UPCB* e US (Thiers, continuamente atualizado). As coleções dos herbários assinalados com asterisco foram analisadas pessoalmente e as outras foram analisadas por meio de imagens digitais no REFLORA - Herbário Virtual (2020) e no INCT - Herbário
Virtual da Flora e dos Fungos (CRIA 2020). Os pontos dos registros foram plotados sobre os mapas fitogeográfico e geológico do Paraná (MINEROPAR 2001, ITCG 2009) no software QGIS (QGIS.org 2016), permitindo a avaliação da preferência ecológica dos táxons.

A descrição de cada espécie foi baseada exclusivamente nos materiais oriundos do Paraná, exceto quando os materiais disponíveis não possuíam estruturas suficientes para a sua descrição. As preferências ecológicas e os dados fenológicos foram obtidos da totalidade do material do Paraná, o qual compõe a lista de coletores. Porém, no material examinado é citado apenas um exemplar de referência por município, exceto quando os materiais históricos foram fundamentais para as análises.

As obras clássicas de Vellozo (1825), Reissek (1861), Warming (1879-1880) e Loesener (1901) foram as principais referências para a identificação dos táxons e para os nomes das espécies, basiônimos e sinônimos. As referências mais recentes consultadas foram das seguintes: Andrews (1985), Brotto et al. (2007), Cabral et al. (2018, 2019), Edwin \& Reitz (1967), Giberti (1990), Groppo \& Pirani (2002, 2005), Viani \& Vieira (2007).

A terminologia morfológica utilizada para o indumento foi baseada em Lawrence (1951) e para as inflorescências em Loizeau \& Spichiger (1992) e Groppo \& Pirani (2002, 2005). As seguintes abreviações foram usadas: compr. para comprimento, diam. para diâmetro e esp. para espessura.

\section{Resultados e discussão}

O Estado do Paraná possui doze espécies de Ilex e duas variedades. Ilex theezans var. gracilior (Warmg.) Loes. foi elevada à espécie, passando a se chamar Ilex gracilior (Warmg.) Brotto.

A Floresta Ombrófila Densa (FOD) abriga nove espécies, a Floresta Ombrófila Mista (FOM) abriga oito, a Floresta Estacional Semidecidual (FES) reúne quatro, a Estepe e a Savana abrigam três espécies cada uma, enquanto que alguns táxons também ocorrem em Formações Pioneiras e Refúgios Vegetacionais. Ilex paraguariensis A.St.-Hil. var.paraguariensis ocorre nas três unidades florestais, Ilex paraguariensis var. vestita (Reissek) Loes. é endêmica da FOM. A análise da distribuição e frequência dos registros no território demonstra que a família se concentra nas regiões de floresta ombrófila. Mesmo Ilex affinis Gardner que é registrada na porção com clima estacional mais acentuado ocorre em hábitat de floresta aluvial e várzea, reforçando a preferência do grupo por ambientes úmidos, tanto em relação à pluviosidade quanto ao solo.

A maior riqueza de espécies é registrada na metade oriental do Estado. A região do Primeiro Planalto que é coberta pela FOM e Estepe (campos de Curitiba), imediatamente a oeste da Serra do Mar, contém nove espécies incluindo uma variedade. A Serra do Mar que é coberta pela FOD e Estepe (campo de altitude) reúne oito ao todo, incluindo uma variedade. A porção oriental do Segundo Planalto iguala a quantidade de espécies encontradas na Serra do Mar, mas abriga duas variedades. A presença da Estepe e da Savana em meio a FOM parece justificar a elevada riqueza neste setor dos Campos Gerais, uma vez que espécies como Ilex asperula Mart. ex Reissek, Ilex brasiliensis (Spreng.) Loes. e Ilex chamaedryfolia Reissek são praticamente exclusivas de vegetação campestre, 
especificamente do campo sujo e do cerrado rupestre, conforme classificação de Ritter et al. (2010).

A identificação dos táxons é baseada principalmente nas folhas e na estrutura das inflorescências, visto que as flores apresentam grande uniformidade interespecífica (Loizeau et al. 2005). Os principais caracteres diagnósticos das folhas são o tamanho, o tipo do indumento, a forma da lâmina, sua consistência, sua margem, além da presença ou ausência de glândulas. Já as inflorescências são diferenciadas principalmente pela forma, comprimento, quantidade de flores e tipo do indumento. Apesar disso, certos táxons apresentam grande variação morfológica, dificultando a delimitação entre as espécies, bem como, inviabilizando o reconhecimento da maioria das variedades e formas descritas por Loesener (1901). Dessa forma, apenas uma nova revisão do gênero baseada em dados genéticos e morfológicos, abrangendo toda a distribuição dos táxons, poderá corroborar ou refutar os táxons com delimitação pouco clara.
Ilex $\mathrm{L}$.

Árvores, arvoretas ou arbustos, dioicos. Ramos velhos com lenticelas. Folhas pecioladas, simples, alternas, cobertas ou não por tricomas tectores, margem variando de inteira a serreada, plana a revoluta, glândulas punctiformes enegrecidas presentes na lâmina ou ausentes; estípulas triangulares, caducas. Inflorescências em dicásios, fascículos, racemos, tirsos ou flores solitárias. Flores unissexuadas, diclamídeas, heteroclamídeas, 4-5-meras, actinomorfas, gamossépalas na base, gamopétalas na base; flor estaminada com androceu isostêmone, estames livres, alternipétalos, adnatos às pétalas pela base; flor pistilada com ovário súpero, sincárpico,4-6 carpelos, 4-6 lóculos, uniovulados, placentação axial, estilete curto ou estigma séssil. Fruto drupa, globoso, sulcado ou não, com cálice e estigma persistentes; 4-6 sementes, envolvidas pelo endocarpocoriáceo, formando pirenos.

Chave de identificação das espécies de Ilex do Paraná

1. Folha com margem inteira ou com dentes diminutos e esparsos

2. Ramo jovem pubérulo; inflorescência pubérula

3. Folha em geral elíptica ou orbicular, face adaxial lustrosa; flor masculina 4-5 mm diam.; estame ca. 1,5 mm compr.........

2.Ilex asperula

3. Folha em geral obovada, face adaxial opaca; flor masculina 6-7 mm diam.; estame 2-2,5 mm compr. ....... 3. Ilex brasiliensis

2. Ramo jovem glabro ou glabrescente; inflorescência glabra ou glabrescente

4. Folha elíptica ou elíptico-ovada, membranácea, margem plana em quase toda a extensão, revoluta apenas na base..... 4. Ilex brevicuspis

4. Folha obovada, oblonga, oblanceolada, raro elíptica, cartácea ou coriácea, margem revoluta em toda a extensão 5. Inflorescência em dicásio solitário; flor masculina ca. $4 \mathrm{~mm}$ diam.; estame ca. $2 \mathrm{~mm}$ compr.; fruto com estigma inconspícuo.

10. Ilex pseudobuxus

5. Inflorescência em aglomerado de dicásios (2-12 por axila); flor masculina 6-10 $\mathrm{mm}$ diam.; estame 2,5-4 mm compr.; fruto com estigma conspícuo.

6. Ramo jovem, pecíolo e inflorescência pubérulos ou glabrescentes; pecíolo $1 \mathrm{~mm}$ esp.; folha cartácea, em geral oblanceolada, ápice agudo, nervura primária levemente sulcada ou plana na face adaxial, flor com pedicelo e lobos do cálice pubérulos, masculina 6-7 $\mathrm{mm}$ de diam.; fruto 5-8 $\mathrm{mm}$ diam. 7. Ilex gracilior

6. Ramo jovem, pecíolo e inflorescência glabros; pecíolo 1,5-3 mm esp.; folha coriácea, em geral obovada ou oblonga, ápice retuso, arredondado ou obtuso, nervura primária sulcada na face adaxial; flor glabra, masculina

7-10 $\mathrm{mm}$ de diam.; fruto 9-13 $\mathrm{mm}$ diam. 12. Ilex theezans

1. Folha com dentes conspícuos e regularmente espaçados na margem

7. Folha com margem crenada

8. Folha com face adaxial lustrosa; inflorescência masculina em tirso com pedúnculo e ráquis de 10-55 $\mathrm{mm}$ compr., feminina em racemo com pedúnculo e ráquis de 10-45 $\mathrm{mm}$ compr. 1. Ilex affinis 8. Folha com face adaxial opaca; inflorescência masculina em tirso com pedúnculo e ráquis de 4-20 mm compr., fascículo, aglomerado de dicásios, dicásio solitário ou flor solitária, feminina em tirso com pedúnculo e ráquis de 2-10 mm compr., fascículo, dicásio ou flor solitária

9. Arbusto muito ramificado; lâmina obovada, estreito-oblanceolada, raro elíptica, com menos de $4 \mathrm{~cm}$ de compr.

5. Ilex chamaedryfolia

9. Árvore; lâmina estreito-elíptica, elíptica, largo-elíptica ou obovada, esta última com 4,5 cm de compr. ou mais

10. Folha elíptica (a maioria), geralmente com glândulas escuras na face abaxial; cálice de lobos ciliados. 6. Ilex dumosa

10. Folha obovada (a maioria), geralmente sem glândulas na face abaxial; cálice de lobos não ciliados. 9. Ilex paraguariensis

7. Folha com margem serreada

11. Folha obovada (a maioria), pecíolo 3-8 mm compr.; inflorescência com flor solitária, raro dicásio com 3 flores, pedúnculo 6-13 mm compr.

8. Ilex microdonta 11. Folha ovada (a maioria), pecíolo 10-25 mm compr.; inflorescência em dicásio com 3 ou 7 flores, pedúnculo 13-30 mm compr. 11. Ilex taubertiana 
1. Ilex affinis Gardner, Icon. P1. 5: 465. 1842.

Figuras $1 \mathrm{a}-\mathrm{b}, 4 \mathrm{a}$

Árvore até $4 \mathrm{~m}$ de alt. Ramo jovem glabro. Folha com pecíolo 5-10 mm compr., canaliculado, rugoso, glabro; lâmina $5-13 \mathrm{~cm} \times 1,7-5 \mathrm{~cm}$, proporção $2-4 \times 1$, elíptica a elíptico-obovada, cartácea a coriácea, glabra, margem revoluta, crenada desde o terço basal, crenas terminando em apículos enegrecidos, ápice curto acuminado, base aguda a cuneada, face adaxial lustrosa, nervura primária levemente sulcada a plana, secundárias levemente salientes, face abaxial com pontuações enegrecidas, nervura primária saliente, secundárias levemente salientes. Inflorescência glabra; masculina em tirso com 10-30 flores, reunidos de 1-5 tirsos por axila, pedúnculo e ráquis 10-55 mm compr.; feminina em racemo com 3 flores, reunidos de 1-3 tirsos por axila, pedúnculo e ráquis 10-45 mm compr. Flor 4(-5)-mera; masculina 4-5 mm diam., pedicelo 1-3 mm compr., lobos do cálice arredondados a triangulares, margem não ciliada, estames ca. 1,5 mm compr. Fruto ca. $4 \mathrm{~mm}$ diam., globoso, estigma persistente, conspícuo; 4 pirenos.

Material examinado: BRASIL. PARANÁ: Guaíra, Sete Quedas, 23-V-1971 (fl.), G. Hatschbach 26699 (K, MBM); Icaraima, rio Paraná, 21-I-1967 (fl.), G. Hatschbach 15780 (MBM, NY, P, UPCB, US); Terra Rica, represa de Rosana, 8-I-1991 (fl.), F. de Barros 2135 (FUEL, SP); Vila Alta, arredores de Porto Figueira, 7-XII-1995 (fl.), J. Carneiro 144 (MBM); Ibidem, Lagoa Azul, 24-I-2003 (fr.), C. Kozera 1827 (MBM).

No Paraná Ilex affinis é encontrada na FES Aluvial e na Formação Pioneira com Influência Fluvial (várzea) sempre sobre depósitos fluviais do Cenozóico entre 220 e 260 metros de altitude. A espécie está restrita a região Noroeste do Estado ocorrendo desde a margem do rio Paraná (limite sul na latitude $24^{\circ} 07^{\prime} S$ ) até a margem do reservatório da UHE Rosana no rio Paranapanema. Dentre as espécies estudadas ela se assemelha a Ilex dumosa, a qual possui folha opaca na face adaxial e inflorescência com no máximo $2 \mathrm{~cm}$ de comprimento, enquanto $I$. affinis apresenta folha lustrosa na face adaxial e inflorescência maior com 4 a $6 \mathrm{~cm}$ de comprimento. Floresce de dezembro a janeiro e em maio, frutifica a partir de janeiro.

2. Ilex asperula Mart. ex Reissek in Mart., Fl. Bras. 11(1): 48. 1861.

Figuras $1 \mathrm{c}-\mathrm{e}, 4 \mathrm{a}$

Arbusto muito ramificado até $1,5 \mathrm{~m}$ de alt. Ramo jovem pubérulo. Folha com pecíolo 2-3 mm compr., canaliculado, pubérulo; lâmina $1,5-5,0 \mathrm{~cm} \times 0,5-2,5 \mathrm{~cm}$, proporção 2-3 $\times 1$, elíptica a orbicular, raro obovada,coriácea, glabra, glabrescente, ou apenas com a nervura primária pubérula, margem revoluta, inteira ou com um par de dentes no ápice, ápice arredondado a obtuso, mucronado, base aguda a obtusa, face adaxial lustrosa, nervuras planas, face abaxial sem pontuações enegrecidas, nervura primária saliente, secundárias levemente salientes. Inflorescência pubérula; masculina em dicásio com 3 flores, reunidos 3 por axila, pedúnculo 2-4 mm compr.; feminina em dicásio com 3 flores, reunidos de 1-4 por axila, ou fascículo com 1-3 flores por axila. Flor 4-5-mera; masculina 4-5 mm diam., pedicelo 1-2 mm compr., lobos do cálice triangulares, margem ciliada, estames ca. 1,5 mm compr. Fruto 4-7 mm diam., globoso, estigma persistente, conspícuo; 4 pirenos.

Material examinado: BRASIL. PARANá: Balsa Nova, São Luiz do Purunã, 23-III-2009 (fr.), M. Selusniaki 2530 (MBM); Bocaiúva do Sul, Serra da Bocaina, 16-I-2001 (fr.), O.S. Ribas 3180 (K, MBM); Jaguariaíva, rio Cajuru, 10-X-1958 (fl.), G. Hatschbach 5069 (MBM, US); Lapa, rio Passa Dois, 13-XI-1999 (fl.), J. Cordeiro 1624 (MBM); Ponta Grossa, Buraco do Padre, 5-XII-2012 (fr. im.), J.M. Silva 8153 (MBM); Tibagi, Parque Estadual do Guartelá, 21-X-1993 (fl.), J. Cordeiro 1119 (ESA, FLOR, K, MBM, NY, RB).

No Estado do Paraná Ilex asperula é encontrada na Estepe, na Savana e no Refúgio Vegetacional Altomontano (campo de altitude) entre 820 e 1.450 metros de altitude. A espécie é amplamente distribuída na metade oriental do Segundo Planalto embora seja pouco comum, principalmente sobre o Arenito Furnas e o Arenito Ponta Grossa onde ocorre preferencialmente em solo bem drenado ou próximo a afloramento rochoso. No Primeiro Planalto ela ocorre apenas na Serra da Bocaina sobre Neossolo quartzítico, hábitat similar aos locais onde é registrada em Minas Gerais (e.g. Serra da Canastra e Cadeia do Espinhaço). Ela é simpátrica com Ilex brasiliensis, a única com quem pode ser confundida. Ilex asperulase diferencia pela folha em geral menor (lâmina 1,5-5,0 cm compr.), elíptica a orbiculare lustrosa na face adaxial, enquanto que Ilex brasiliensis apresenta folha maior (lâmina 3,5-9,3 cm compr.), obovada e não lustrosa. Floresce de setembro a novembro, além de maio e junho, frutifica de novembro a março.

3. Ilex brasiliensis (Spreng.) Loes. in Engl. \& Prantl, Nat. Pflanzenfam. Nachtr. 1: 220. 1897.

Figuras 1 f-i, 4 b

Arbusto ou arvoreta até $5 \mathrm{~m}$ de alt. Ramo jovem pubérulo. Folha com pecíolo 4-12 mm compr., canaliculado, pubérulo; lâmina 3,5-9,3 cm ×1,5-4,2 cm, proporção 1,5-2,2× 1, obovada, raro elíptica, coriácea, pubérula a glabrescente, margem fortemente revoluta, inteira, ocasionalmente com poucos dentes no terço apical, ápice retuso a arredondado, mucronado, base aguda, face adaxial opaca, nervura primária levemente sulcada a plana, secundárias planas ou inconspícuas, face abaxial com pontuações inconspícuas, nervura primária saliente, secundárias levemente salientes. Inflorescência pubérula; masculina em dicásio com 3 flores, reunidos de 3-10 por axila, pedúnculo 3-7 mm compr.; feminina em fascículo com 3-6 flores por axila. Flor 4-5mera; masculina 6-7 mm diam., pedicelo 1-4 mm compr., lobos do cálice arredondados a triangulares, margem não ciliada, estames 2-2,5 mm compr. Fruto 4-6 mm diam., globoso, estigma persistente, conspícuo; 4-5 pirenos.

Material examinado: BRASIL. PARANÁ: Apucarana, Parque da Raposa, 30-X-1996 (fl.), F. Chagas e Silva 2040 (FUEL); Arapoti, rio das Perdizes, 11-X-1968 (fl.), G. Hatschbach 19999 (MBM); Cianorte, Fazenda Lagoa, 24VIII-1967 (fl.), G. Hatschbach 16947 (MBM, NY, P, UPCB, US); Balsa Nova, Tamanduá, 12-XI-1980 (fl.), G. Hatschbach 43351 (K, MBM, NY, US); Campo Largo, Bateias, 19- 
VI-2014 (fr.), C.L. Ribeiro 102 (EFC); Campo Mourão, Rio Mourão, 2-V-1997 (fr.), C.V. Roderjan 1402 (EFC); Carambeí, Rio São João, 15-I-1965 (fr.), G. Hatschbach 12145 (MBM, NY); Céu Azul, Parque Nacional do Iguaçu, 5-X-2017 (fl.), M.G. Caxambu 7926 (ALCB, HCF); Cianorte, Fazenda Lagoa, 28-IV-1966 (fr.), G. Hatschbach 14256 (MBM, UPCB, US); Jaguariaíva, Rio Diamante, 20-XI-2018 (fr. im), M.L. Brotto 3177 (MBM); Londrina, Fazenda Prata, 25-II-1999 (fr.), E.M. Francisco s.n. (FUEL 24829, HUEM 5328); Mauá da Serra, Fazenda Prata, 22-IX-1998 (fl.), E.M. Francisco s.n. (DPR 782, ESA 62904, FUEL 21851, MBM 239719, SP 338597, SPF 139069); Medianeira, próximo ao Rio Capanema, 23-XII-1966 (fr.), J.C. Lindeman s.n. (MBM 7471); Palmeira, Rio Tibagi, 22-X-1965 (fl.), G. Hatschbach 13044 (MBM, P, UPCB, US); Piraí do Sul, Fazenda Nova Era, 15-II-2013 (fr. im.), M.L. Brotto 957 (MBM, RB); Ponta Grossa, Parque Estadual de Vila Velha, 5-X-1989 (fl.), A.C. Cervi 2800 (UPCB); Rio Branco do Sul, Santa Cruz, 24-III1971 (fr.), G. Hatschbach 26589 (K, MBM); São Jerônimo da Serra, Reserva Indígena de São Jerônimo, 23-VII-2004 (fr.), K.L.V.R. de Sá 193 (FUEL); São Tomé, Fazenda Lagoa, 3-IV-1966 (fr.), J.C. Lindeman 1969 (MBM); Sengés, Serra do Mocambo, 19-IX-1975 (bot.), G. Hatschbach 37107 (K, MBM); Tamarana, Fazenda Prata, 8-VI-1999 (fr), D.A. Estevan 6 (DVPR, FUEL); Tibagi, Cânion Guartelá, 28X-1995 (fr. im.), F. Chagas e Silva 1862 (ESA, FUEL, K, MBM); Tuneiras do Oeste, 12-XI-2013 (fr. im), E.D. Lozano 1773 (MBM, RB, UPCB); Ventania, Campo de Fora, 23-VII2004 (fr. im.), D.A. Estevan 401 (FUEL, MBM).

No Paraná Ilex brasiliensis é encontrada nas bordas de fragmentos da FOM Montana, na Estepe, na Savana e na Formação Pioneira com Influência Fluvial (várzea) entre 700 e 1.200 metros de altitude. A espécie é amplamente distribuída no Segundo Planalto onde apresenta frequência mediana, ocorrendo preferencialmente sobre rochas dos Grupos Itararé e Paraná em margem de rios ou próxima a afloramentos rochosos. No Terceiro Planalto ela é pouco frequente, ocorrendo nos relictos de Savana em meio a FES sobre rochas basálticas, enquanto que no Primeiro Planalto ela é registrada apenas em morros de embasamento quartzítico, assim como Ilex asperula. Difere desta por possuir folha maior, obovada e opaca na face adaxial, enquanto que Ilex asperula possui folha em geral menor, elíptica a orbicular e lustrosa. Também pode ser confundida com espécimes de Ilex theezans que possuem folhas obovadas, no entanto, esta apresenta ramos jovens glabros e inflorescências glabras, enquanto que Ilex brasiliensis possui indumento pubérulo. Floresce de agosto a novembro e frutifica de outubro a julho.

\section{Ilex brevicuspis Reissek in Mart., Fl. Bras. 11(1): 56.1861.} Figuras 1 j-m, 4 b

Arbusto ou árvore até $25 \mathrm{~m}$ de alt. Ramo jovem glabrescente. Folha com pecíolo 5-15 mm compr., canaliculado, glabrescente; lâmina 3,0-7,5 cm $\times 1,0$ $2,4 \mathrm{~cm}$, proporção $3 \times 1$, elíptica a elíptico-ovada, membranácea, glabra, margem plana a revoluta apenas na base, variadamente serreada a partir do terço basal até inteira, com dentes diminutos e esparsos, um par de dentes próximo à base, ápice geralmente apiculado a agudo, base atenuada, face adaxial opaca, nervura primária levemente sulcada a plana, secundárias planas, face abaxial sem pontuações enegrecidas, nervura primária saliente, secundárias planas. Inflorescência glabrescente; masculina em dicásio com 3 flores, raro 7 flores, reunidos de 4-5 por axila, pedúnculo 2-9 mm compr.; femininas em dicásio com 3 flores, reunidos de 4-6 por axila, pedúnculo 2-14 mm compr. Flor 4-mera; masculina 4-5 $\mathrm{mm}$ diam., pedicelo 3-4 mm compr., lobos do cálice arredondados a triangulares, margem não ciliada, estames ca. 2,3 mm compr. Fruto 3-5 mm diam., globoso, sulcado, estigma persistente, conspícuo.

Material examinado: BRASIL. PARANÁ: Adrianópolis, Fazenda Mato Limpo, Berneck, 23-XI-2004 (fl.), J.M. Silva 4212 (HCF, MBM, RB); Apucarana, Parque da Raposa, 19XI-2002 (fl.), E.M. Francisco 129(FUEL); Bituruna, Fazenda Lageado Grande, 23-I-2005 (fr.), D. Liebsch 1020 (HFC, UPCB); Bocaiúva do Sul, 26-XI-1986 (fl.), G. Hatschbach 50805 (K, MBM, US); Campo Largo, 19-I-1880 (fr. im.), C.A.W. Schwacke 2475 (ALCB, RB); Campo Mourão, Parque Municipal do Lago, 2-III-2004 (fr.), A.E. Bianek 208 (HCF, MBM); Cascavel, Parque Ecológico Paulo Gorski, 11-XI2012 (fl.), J.P. Borges 85 (RB, UNOP, UPCB); Clevelândia, Granja Palmar, 5-III-1991 (fr.), J.M. Silva 939 (FUEL, MBM, US); Curitiba, Lar das Meninas, 20-XI-1978 (fl.), N. Imaguire 5391 (MBM); Curiúva, Fazenda São José, 24-XI-1999 (fr. im.), O.C. Pavão s.n. (FUEL 27687, SP 365821); Doutor Ulysses, Rio Turvo, 19-IV-2006 (fr. im.), E. Barboza 1256 (MBM); Foz do Iguaçu, Parque Nacional de Foz do Iguaçu, 7-XII-1992, S.A. Nicolau 1086 (FUEL); General Carneiro, 13-XII-1966 (fl.), G. Hatschbach 15395 (MBM, NY, P, UPCB, US); Guarapuava, Parque Municipal das Araucárias, 8-X-2004 (fl.), Juliano Cordeiro 248 (MBM); Guaraqueçaba, Rio do Cedro, 21-XI-1968 (fl.), G. Hatschbach 20371 (K, MBM, NY); Irati, 20-IV-1983 (fr.), J.R. Pirani 574 (FUEL, SPF); Lapa, Água Amarela, 8-II-1966 (fr.), G. Hatschbach 13670 (MBM, NY, US); Laranjeiras do Sul, Campo Novo, 7-XI-1966 (fl.), J.C. Lindeman 2890 (K, MBM, US); Londrina, Parque Estadual Mata dos Godoy, 8-III-1996 (fr.), F. Chagas e Silva s.n. (FUEL 17382); Mandirituba, 1-II-1983 (fr.), Y.S. Kuniyoshi 4610 (MBM); Morretes, rio Mãe Catira, 14-XII-1969 (fl.), G. Hatschbach 23235 (K, MBM, NY); Ortigueira, 6-XI-1998 (fl.), O.C. Pavão s.n. (DVPR783, FUEL 24833, MBM 239721); Palmas, 12-XII-1980 (fl.), $G$. Hatschbach 43447 (MBM, NY, SPF); Palmeira, 20-XII-1929 (fl.), L. Gurgel s.n.(MBM 342631, RB 136264); Paranaguá, Serra da Prata, 15-XII-1948 (fl.), G. Tessmann 3597 (MBM, UPCB); Pinhão, Barbaquá, 17-III-1967 (est.), J.C. Lindeman 4954 (MBM); Piraquara, Volta Grande, XII-1943 (fl.), $R$. Hertel s.n. (MBM); Ponta Grossa, 13-IV-1911 (fr.), P.K. Dusén 11628 (NY); Quedas do Iguaçu, Fazenda Giacomet, 30-X-1991 (fl.), A.M.L. Cassanello s.n. (UPCB 19029); Rio Branco do Sul, 26-II-1912 (fr.), P.K. Dusén 13884 (K); São Jerônimo da Serra, Rancho Carolina (fl.), E.M. Francisco s.n. (ESA 62930, FUEL 22306, MBM 239720, UEC 109017); São João do Triunfo, Colônia Palmeira, 19-IV-1979 (fr.), G. Hatschbach 42179 (MBM); São José dos Pinhais, 12-XII1947 (fl.), G. Tessmann 2736 (MBM); São Mateus do Sul, Fazenda do Durgo, 30-XI-1986(fl.), R.M. Britez 1228(MBM, UPCB); Sertanópolis, Fazenda Fartura, 28-IX-2000 (bot.), 
O.C. Pavão 16 (FUEL); Tamarana, Acampamento Água Viva, 1-XI-2000 (fl.), E.M. Francisco s.n. (FUEL 43088); Teixeira Soares, rio da Areia, 8-III-1990 (fr. im.), J.M. Silva 823 (FLOR, MBM, US); Telêmaco Borba, Fazenda Monte Alegre, 2-VIII-1981 (fr. im.), L.H. Soares-Silva 285 (FUEL, K, UEC); Tibagi, Fazenda Batavo, 16-I-1991 (fl.), F. Chagas e Silva 1568 (FUEL, K, MBM); Tijucas do Sul, Tabatinga, 1-XII-1964 (fl.), G. Hatschbach 11918 (MBM); Tunas do Paraná, 4-XII-2017 (fl.), M.L. Brotto 2546 (MBM); União da Vitória, Rio Santa Maria, 3-XII-1971 (fl.), G. Hatschbach 28155 (K, MBM).

No Paraná Ilex brevicuspis é encontrada na FES, na FOM ena FOD Montana e Submontana entre 50 e 1.200 metros de altitude. A espécie é amplamente distribuída e comum nos planaltos acima dos $800 \mathrm{~m}$ de altitude, enquanto que na região da Serra do Mar ela é pouco frequente. $\mathrm{Na}$ FES são conhecidos registros apenas nas regiões de Foz do Iguaçu e de Londrina. Ocorre sobre uma variedade de rochas ígneas, metamórficas e sedimentares. Na época de floração é comum as árvores estarem parcialmente decíduas com muitas inflorescências ao longo dos ramos e poucas folhas próximas ao ápice. As folhas são variadamente serreadas, o que significa que em um mesmo indivíduo podem ocorrer folhas com a margem serrada desde o terço basal até folhas com margem inteira. Indivíduos que possuem folhas com vários dentes, ainda que diminutos, podem ser confundidos com Ilex taubertiana. Entretanto, esta espécie possui lâmina de consistência cartácea a coriácea e margem revoluta, enquanto I. brevicuspis possui lâmina membranácea e margem plana ou revoluta apenas na base. O mesmo aspecto da consistência da lâmina e a margem quase inteiramente plana servem para diferenciá-la de Ilex gracilior e Ilex pseudobuxus, as quais possuem lâminas cartáceas a coriáceas e margem revoluta, diferindo também pela forma das lâminas. Floresce de outubro a janeiro e frutifica de janeiro a maio, e excepcionalmente em agosto e novembro.

\section{Ilex chamaedryfolia Reissek in Mart., Fl.Bras. 11(1):} 73. 1861 .

Figuras 2 a-c, 4 c

Arbusto muito ramificado até $3 \mathrm{~m}$ de alt. Ramo jovem glabro a pubérulo. Folha com pecíolo 1-6 mm compr., canaliculado, glabrescente; lâmina 1,2-3,8 cm $\times 0,6-1,7 \mathrm{~cm}$, proporção 1,5-1,5 × 1, obovada, raro elíptica, ou 1,6-3,5 cm $\times 0,4-0,8 \mathrm{~cm}$, proporção 4-4,5 × 1, estreito-oblanceolada a obovada, raro elíptica, coriácea, glabra, margem revoluta, crenada a partir da metade ou desde próximo à base, crenas terminando em apículos enegrecidos, ápice arredondado a agudo, base cuneada, face adaxial opaca, nervuras primária levemente sulcada a plana, secundárias inconspícuas, face abaxial com ou sem pontuações enegrecidas, nervura primária saliente, secundárias levemente salientes a planas. Inflorescência glabrescente; masculina com flores solitárias, 1-3 por axila; ou em dicásio com 3 flores, 1 por axila, pedúnculo 5-8 mm compr.; feminina com flores solitárias, 1-4 por axila, ou em tirso curto com 5 flores, 1 por axila, pedúnculo 2-3 mm compr. Flor 4-mera; masculina $5 \mathrm{~mm}$ diam., pedicelo 3,5 mm compr., lobos do cálice arredondados, margem não ciliada, estames ca. $2 \mathrm{~mm}$ compr. Fruto ca. $4 \mathrm{~mm}$ diam., globoso, estigma persistente, inconspícuo; 4 pirenos.

Material examinado: BRASIL. PARANÁ: Arapoti, Rio das Cinzas, 10-X-1968 (fl.), G. Hatschbach 19965 (MBM, NY); Bocaiúva do Sul, Serra da Bocaina, 17-XI-2000 (fl.), E. Barboza 616 (K, MBM); Campina Grande do Sul, Serra do Capivari, 18-IV-2014 (fr.), M.L. Brotto 1611 (HCF, MBM, RB); Campo Largo, Serra de São Luiz do Purunã, 4-XII-1949 (fl.), G. Hatschbach 1632 (MBM); Castro, II-1861 (fl.), J. Weir 329 (K); Guaratuba, Morro dos Perdidos, 24-X-2001 (bot.), E.P.Santos 1073 (HUCP, UPCB); Jaguariaíva, rio Diamante, 20-XI-2018 (fl.), M.L. Brotto 3173(MBM); Ponta Grossa, rio São Jorge, 9-XI-1989 (fl.), A.C. Cervi 3014 (FLOR, MBM, UPCB); Morretes, Parque Estadual Pico do Marumbi, 16-IX1997 (fr. im.), C.V. Roderjan 1422 (EFC); Palmeira, Rio dos Papagaios, 28-X-1983 (fl.), A.C. Cervi 2207 (NY, UPCB); Piraquara, Morro do Canal, 18-XI-2010 (fl.), M.L. Brotto 495 (MBM); Ponta Grossa, Rio São Jorge, 9-XI-1989 (fl.), A.C. Cervi 3014 (FLOR, MBM, UPCB); Quatro Barras, morro Mãe Catira, 4-VIII-1966 (fr.), G. Hatschbach 14558 (MBM, NY, P, UPCB, US); Tijucas do Sul, Pico Araçatuba, 16-III-2008 (fr.), M.L. Brotto 84 (UPCB).

No Paraná Ilex chamaedryfolia é encontrada na FOD Altomontana (com no máximo 3 metros de altura) e no Refúgio Vegetacional Altomontano (campo de altitude), ambos no alto das montanhas da Serra do Mar e vale do rio Açungui. Também pode ser encontrada na Estepe e em relictos de Savana preferencialmente sobre os Arenitos Furnas e Ponta Grossa, ambos no Segundo Planalto. É pouco comum em toda essa área de distribuição. Dentre as espécies que ocorrem no Estado pode ser confundida com Ilex dumosa, a qual possui folha maior (lâmina 2,5-8,0 cm compr.), geralmente elíptica e hábito arbóreo, enquanto que Ilex chamaedryfolia apresenta folha menor (lâmina 1,2-3,8 cm compr.), geralmente estreito-oblanceolada a obovada e hábito arbustivo. Na fase vegetativa também se assemelha muito a Monteverdia glaucescens (Reissek) Biral, uma Celastraceae que ocorre nos mesmos hábitats (Santos 2016). Ambos são arbustos muito ramificados com folhas obovadas pequenas e flores de tamanho semelhante. Porém, Ilex chamaedryfolia pode ser reconhecida pela flor gamopétala e fruto do tipo drupa, enquanto que Monteverdia glaucescens possui flor dialipétala e fruto tipo cápsula bivalvar. Floresce de outubro a julho, com concentração em outubro e novembro, e frutifica de dezembro a setembro.

Na Flora da Serra do Cipó/MG,Groppo \& Pirani (2005) incluíram na circunscrição de Ilex dumosa espécimes com forma arbustiva, folhas menores, mais coriáceas e geralmente mais arredondadas, o que equivale aos fenótipos de Ilex chamaedryfolia encontrados no Paraná. Em oposição ao conceito adotado por esses autores, aqui considero consistente a separação dos arbustos com folhas congestas que tendem ao padrão obovado e que florescem a partir dos $50 \mathrm{~cm}$ até os $3 \mathrm{~m}$ de altura em relação às árvores e arbustos com folhas elípticas e não congestas de Ilex dumosa. Além disso, nas coleções analisadas foi possível reconhecer espécimes que poderiam se enquadrar nas duas variedades descritas por Loesener (1901). No geral aqueles oriundos da Serra do Mar possuem folhas largas, obtusas, assim como Ilex chamaedryfolia var. typica 
Loes., enquanto que outros coletados no Segundo Planalto possuem folhas estreito-oblanceoladas assim como Ilex chamaedryfolia var. mugiensis Loes. Apesar dessa tendência, também há exceções como a presença da variedade mugiensis na Serra do Mar e da variedade typica no Segundo Planalto, além de espécimes intermediários, impossibilitando uma definição clara dessas variedades. Isso me levou a optar pelo conceito de Ilex chamaedryfolia sensu lato.

6. Ilex dumosa Reissek in Mart., Fl. Bras. 11(1): 64. 1861. Figuras $2 \mathrm{~d}-\mathrm{f}, \mathrm{d}$

Árvore até $12 \mathrm{~m}$ de alt. Ramo jovem glabro a glabrescente. Folha com pecíolo 3-10 mm compr., canaliculado, pubescente; lâmina 2,5-8,0 cm × 1,0-3,2 $\mathrm{cm}$, proporção $2-4,4 \times 1$, estreito-elíptica a largo-elíptica, coriácea, glabra, margem revoluta, crenada a partir da base, crenas terminando em apículos enegrecidos, ápice agudo a curto-acuminado, base aguda, face adaxial opaca, nervura primária sulcada, secundárias levemente sulcadas ou inconspícuas, face abaxial com pontuações enegrecidas, nervura primária saliente, secundárias levemente salientes. Inflorescência pubescente; masculina em tirso curtocom 5-25 flores, junto com 1-3 flores solitárias, reunidos nas axilas, ou dicásio com 3 flores, reunidos 4 por axila, pedúnculo e ráquis 4-20 mm compr.; feminina em tirso curto com 6-13 flores, 1 por axila, pedúnculo 2-10 $\mathrm{mm}$ compr., ou fascículo com 4 flores. Flor 4-mera; masculina 5-6 mm diam., pedicelo 1-2 mm compr., lobos do cálice arredondados, margem não ciliada, estames ca. $2 \mathrm{~mm}$ compr. Fruto 3-6 mm diam., globoso, estigma persistente, conspícuo; 4 pirenos.

Material examinado: BRASIL. PARANá: s.d., F. Sellow 4633 (sintipo de Ilex amara var. latifolia Reissek- barcode K001046886 [foto!]); s.d., F. Sellow 4683 (sintipo de Ilex amara var. latifolia Reissek fo. microphylla Loes. - barcodes BR0000006974206 [foto!], K001046930 [foto!]); bois prés Fortaleza, s.d., A. Saint-Hilaire C2-1474 (sintipo de Ilex amara var. latifolia Reissek fo. microphylla Loes. - barcodeP02142123[foto!]); Almirante Tamandaré, 9-XI2018 (fl.), R.R. Völtz 1956 (UEC); Antonina, 14-XII-1879 (fl.), C.A.W. Schwacke 2470 (sintipo de Ilex amara var. latifolia Reissek fo. microphylla Loes. - barcodeRB00047282 [foto!]); Apucarana, Parque da Raposa, 30-X-1996 (fl.), F. Chagas e Silva 2039 (FUEL); Araruna, Fazenda Floresta Negra, 6-X-2015 (bot.), E.L. Siqueira 1724 (FURB, HCF, MBM); Araucária, 26-X-1970 (bot.), K. Motizuki s.n. (EFC 1932); Bocaiúva do Sul, 26-XI-1986 (fl.), G. Hatschbach 50804 (MBM, US); Campina Grande do Sul, Rio Taquari, 9-XII-1957 (fl.), G. Hatschbach 4002 (MBM, UPCB, US); Campo do Tenente, 26-X-2016 (bot.), S.V.S. Costa Filho 7 (EFC); Campo Largo, 19-I-1880 (fr.), C.A.W. Schwacke 2474 (sintipo de Ilex amara var. latifolia Reissek fo. microphylla Loes. - barcode RB00047277[foto!]); Campo Mourão, vila Franciscana, 12-XII-2017 (fr.), E.L.Siqueira 2425 (HCF); Cascavel, Parque Ecológico Paulo Gorski, 11-XI-2012 (fr.), J.P. Borges 97 (RB, UNOP); Castro, Rio Cunhaporanga, 17-XI-1988 (fl.), S.M. Silva 1658 (MBM); Clevelândia, 21-XI-1972 (fl.), G. Hatschbach 30795 (MBM); Colombo, Embrapa, 25-II-1982 (fr.), C.V. Roderjan 35 (EFC, HCF, K, MBM); Contenda, Campina dos Vale, 15-X-1958 (fl.), $G$.
Hatschbach 5154 (MBM, US); Curitiba, Bacacheri, 26-XI1984 (fl.), G. Hatschbach 48576 (FLOR, MBM); Fazenda Rio Grande, Passo Amarelo, 8-XI-1998 (fl.), A. Dunaiski Jr. 949 (HUCP, UPCB); General Carneiro, cabeceira do rio Iratim, 11-II-1966 (fr.), G. Hatschbach 13699 (K, MBM, NY); Guarapuava, 8-XI-2011 (fr.), P.K. Dusén 11076 (K, NY, P); Guaraqueçaba, caminho do Paruquara 23-I-1991 (fr.), G. Hatschbach 54908 (K, NY, MBM); Guaratuba, Rio Boguassú, 11-XII-1957 (fl.), G. Hatschbach 4301 (MBM, US); Irati, Colégio Estadual Florestal, 25-IX-1972 (fl.), P. Carvalho 22 (MBM); Itaperuçu, 29-XI-1964 (fl.), L.T. Dombrowski 987 (MBM); Jaguariaíva, Rio do Sabiá, 28XI-1968 (fr.), G. Hatschbach 20442 (MBM, UPCB); Lapa, Passa Dois, 2-XI-1965 (fl.), R. Braga 31 (RB, UPCB, US); Mandirituba, Rio Barigui, 30-XI-1981 (fl.), L.R. Landrum 3888 (MBM, NY); Mangueirinha, PCH Tigre, 14-XI-2016 (fl.), J.M. Silva 9602 (HCF, MBM); Marmeleiro, 21-II-1971 (fr.), G. Hatschbach 26389 (MBM); Matinhos, 16-XI-1963 (fl.), L.T. Dombrowski 136 (MBM); Medianeira, próximo ao Rio Iguaçu, 23-XII-1966 (fl.), J.C. Lindeman 3369 (K, MBM, RB); Morretes, Estrada da Graciosa, 20-I-1987 (fr.), G. Hatschbach 50876 (FLOR, K, MBM, UPCB); Ortigueira, Morro da Pedra Branca, 17-X-2014 (fl.), M.G. Caxambu 5611 (FURB, HCF, MBM, RB); Palmas, Santo Agostinho, 13-XII-1966 (fl.), G. Hatschbach 15421 (MBM, UPCB, US); Palmeira, Fazenda Boiada, 7-III-1965 (fr.), G. Hatschbach 12457 (MBM); Paranaguá, Ilha do Mel, 27-XI-1970 (fl.), G. Hatschbach 25637 (MBM, RB, UPCB); Pato Branco, Independência, 4-III-1991 (fr.), J.M. Silva 929 (MBM, SPF, UPCB); Paulo Frontin, Vicinal 9, 7-XI-2005 (fl.), $R$. Wasum 3188 (MBM); Piên, Poço Frio, 6-X-1987 (bot.), G. Hatschbach 51486 (K, MBM); Pinhão, Barbaquá, 16-III1967 (est.), J.C. Lindman 4934B (MBM); Piraquara, rio Piraquara, 8-XI-1969 (fl.), G. Hatschbach 22858 (MBM, NY, UPCB); Pitanga, Pedreira São Judas Tadeu, 18-X-2006 (fl.), A.E. Bianek 301 (HCF, MBM); Ponta Grossa, 28-XI1993 (fr. im), F. Chagas e Silva 1659 (FUEL, K, MBM); Pontal do Paraná, Ipanema, 23-XI-1994 (fl.), J. Cordeiro 1206 (FLOR, K, MBM, NY); Porto Amazonas, 21-X-1931 (bot.), L. Gurgel 16138 (CEPEC, NY, RB); Quatro Barras, Morro Anhangava, 17-XI-1992 (fl.), C.V. Roderjan 1106 (EFC, FLOR, K, MBM); Quitandinha, Cerrinho, 24-XI1964 (fl.), G. Hatschbach 11891 (MBM); Reserva, Fazenda Barra Mansa, 10-XI-1998 (fl.), E.M. Francisco s.n. (DVPR 785, FUEL22354, MBM 239722); São Jerônimo da Serra, 25-X-2000 (fl.), C.M. Sakuragui 1221 (HUEM); São João do Triunfo, 22-VII-1966 (est.), J.C. Lindman 1916(MBM); São José dos Pinhais, Guaricana, 5-XI-1975 (fl.), G. Hatschbach 34907 (MBM); São Mateus do Sul, 6-II-1931 (fl.), L. Gurgel 16089 (MBM, RB); Teixeira Soares, Fazenda Capão Bonito, 1-VII-1991 (est.), F. Chagas e Silvas s.n. (FUEL 17315); Telêmaco Borba, Fazenda Monte Alegre, 20-XI-1989 (fl.), G. Hatschbach 2858 (MBM); Tibagi, Rio Capivari Grande, 19-XI-1969 (fl.), G. Hatschbach 22945 (MBM); Tijucas do Sul, Ambrósio, 22-IX-1977 (fl.), G. Hatschbach 40181 (MBM); Tuneiras do Oeste, 8-X-2013 (fl.), M. Caxambu 4810 (HCF, MBM); União da Vitória, 29-XII-1967 (fr. im), C. Koczicki 47 (MBM). 
No Paraná Ilex dumosa é encontrada na FOD das Terras Baixas, Submontana, Montana e Aluvial; na FOM; e na FES Submontana (apenas em Medianeira); e nas Formações Pioneiras com Influência Fluvial e Marinha; entre 2 e 1.200 metros de altitude. É amplamente distribuída nas regiões com vegetação ombrófila sendo comum em todas, exceto na Serra do Mar. Ocorre sobre uma variedade de rochas ígneas, metamórficas e sedimentares. Espécimes com folhas grandes se assemelham a Ilex paraguariensis, da qual difere principalmente pelas folhas elípticas com pecíolo menor (3-10 $\mathrm{mm}$ ), enquanto que a outra apresenta folhas obovadas com pecíolo maior $(6-13 \mathrm{~mm})$. Espécimes com folhas pequenas se assemelham a Ilex chamaedryfolia, a qual possui folhas menores $(1,2-3,8 \mathrm{~cm})$, geralmente estreito-oblanceoladas ou obovadas e hábito arbustivo. Floresce de setembro a fevereiro, com concentração em outubro e novembro, e frutifica de novembro a julho, excepcionalmente em setembro.

Loesener (1901) descreveu quatro variedades de Ilex dumosa e ainda citou espécimes coletados no Paraná entre as variedades e formas de Ilex amara (Vell.) Loes. Com base na grande amplitude de fenótipos analisados eu concluo que não é viável o reconhecimento de todos os táxons envolvidos em virtude da falta de separação clara entre eles. Para melhor delimitação será necessária uma revisão desse complexo de espécies. Por isso nesse estudo é adotado o conceito de Ilex dumosa sensu lato. Este é o nome mais utilizado no Estado apesar de Ilex amara ter prioridade nomenclatural.

\section{Ilex gracilior (Warmg.) Brotto, stat. nov.}

Figuras 2 g-i, 5 a

Árvore até $12 \mathrm{~m}$ de alt. Ramo jovem pubérulo a glabrescente. Folha com pecíolo 5-10 mm compr., canaliculado, pouco rugoso, pubérulo, raro glabrescente, $1 \mathrm{~mm}$ esp.; lâmina 2-8, $2 \times 1-3 \mathrm{~cm}$, proporção 2-3,3 × 1, oblanceolada, raro obovada, simétrica, cartácea, glabrescente, margem revoluta, inteira ou com poucos dentes na metade apical, ápice agudo, raro acuminado ou obtuso, às vezes com um apículo muito curto, base aguda, face adaxial opaca, nervura primária levemente sulcada a plana, secundárias planas a levemente salientes, face abaxial sem pontuações, nervura primária saliente, secundárias levemente salientes, ângulo de $55^{\circ}-85^{\circ} \mathrm{em}$ relação à primária. Inflorescência pubérula, raro glabrescente; masculina em dicásio com 3 flores, reunidos de 2-5 por axila, pedúnculo 4-10 mm compr.; ou em fascículo com 3-5 flores por axila; femininas em fascículo com 2-5 flores por axila. Flor 5(-4)-meras; masculina 6-7 mm diam., pedicelo 2,5-3 mm compr., lobos do cálice triangulares, pubérulos, margem ciliada, estames 2,5-3,5 mm compr. Fruto 5-8 mm diam., globoso ou ovoide, estigma persistente, conspícuo; 4-5 pirenos.

Material examinado: BRASIL. Paraná: s.d. (fl.), $F$. Sellow 4952 (barcode K001046515 [foto!]); Almirante Tamandaré, morro próximo à cidade, 15-X-2020 (fl.), M.L. Brotto 4000 (BHCB, ESA, MBM, RB); Bocaiuva do Sul, Colônia João XXIII, 26-X-2005 (fl.), O.S. Ribas 7025 (MBM, RB); Colombo, Embrapa, 21-X-1986 (fl.), Y.S. Kuniyoshi 5048 (EFC, K, MBM); Piraquara, Mananciais da Serra, 13X-2001 (fl.), P.H. Labiak 1941 (MBM); Recreio da Serra, 9-II-2020 (fr. im.), M.L. Brotto 3706 (EFC, ESA, FLOR, HCF, HUPG, MBM, RB); Ibidem, 8-XI-2020 (fl.), M.L.
Brotto 4024 (EFC, ESA, BHCB, FLOR, HCF, HUPG, K, MBM, NY, RB); Tijucas do Sul, Matulão, rio Fojo, 18-X1997 (fr. im), J.M. Silva 1979 (K, MBM, SPF).

No Paraná Ilex gracilior é encontrada na FOD Montana e Altomontana ao longo do eixo principal da Serra do Mar sobre granitos e na FOM Montana da metade oriental do Primeiro Planalto sobre migmatitos e quartzitos entre 900 a $1.200 \mathrm{~m}$ de altitude. É pouco comum em ambas as regiões sendo simpátrica com Ilex theezans em toda a sua área de distribuição, com a qual pode ser confundida. Também se assemelha com Ilex brevicuspis devido às suas folhas pequenas, boa parte delas com 3 ou 5 dentes diminutos no ápice agudo. Porém, Ilex brevicuspis possui folhas elípticas a elíptico-ovadas, membranáceas e de margem plana em quase toda a extensão, enquanto que Ilex gracilior apresenta folhas oblanceoladas, raro obovadas, cartáceas e de margem revoluta em toda a extensão. Floresce de setembro a outubro, excepcionalmente em julho, e frutifica de outubro a maio, excepcionalmente em agosto.

Ilex gracilior reúne um conjunto de características suficientemente distintas dos outros fenótipos de Ilex theezans existentes no Paraná, tanto na comparação entre materiais herborizados quanto na comparação entre árvores vivas. Por isso eu estou propondo um status novus para Ilex theezans var. gracilior (Warmg.) Loes. Ela se diferencia nitidamente dos espécimes de Ilex theezans com folhas grandes $(>8,2 \mathrm{~cm})$ e pecíolos longos $(>10 \mathrm{~mm})$. Por sua vez, os materiais de Ilex theezans com folhas pequenas são os que mais se assemelham a Ilex gracilior. Mesmo que as folhas tenham o comprimento equivalente, I. theezans possui pecíolos com o dobro da espessura (1,5-3 mm versus $1 \mathrm{~mm}$ em I. gracilior), lâmina nitidamente obovada com ápice obtuso, coriácea, a nervura primária sulcada na face adaxial e ângulo desta com as nervuras secundárias menor $\left(35^{\circ}-75^{\circ}\right.$ versus $55^{\circ}-85^{\circ} \mathrm{em}$ I. gracilior), além de flores glabras e frutos maiores.

A decisão de elevar a variedade para espécie também se baseou na comprovação de que árvores desses dois táxons ocorrem lado a lado nas mesmas condições ambientais, o que reforça a hipótese de uma significativa distância genética que justifique tal classificação taxonômica. Isso foi constatado na localidade de Recreio da Serra, município de Piraquara, por meio dos vouchers M.L. Brotto 3705 e 4023 (I. theezans) em comparação com 3706 e 4024 (I. gracilior) que são nitidamente distintos. O mesmo foi constatado no município de Almirante Tamandaré por meio dos vouchers M.L. Brotto 4001 (I. theezans) e 4000 (I. gracilior), também distintos. Nesses locais foi possível observar que as árvores de Ilex theezans possuem folhas de cor verde-escuro que depois de herborizadas adquirem cor verde-oliva e os frutos ficam marrom-escuros. Ao contrário, as árvores de Ilex gracilior possuem folhas de cor verde-claro que depois de herborizadas adquirem cor acinzentada e os frutos se tornam castanhos. Esses padrões de coloração se repetem nas demais coleções de herbários.

8. Ilex microdonta Reissek in Mart., Fl. Bras. 11(1): 41.1861. Figuras 2 j-1, 4 a

Arbusto ou árvore até $10 \mathrm{~m}$ de alt. Ramo jovem glabro. Folha com pecíolo 3-8 $\mathrm{mm}$ compr., canaliculado, 
glabro; lâmina 2,5-4 cm × 1,2-2,7 cm, proporção 1,5-2 × 1, obovada, raro elíptica, cartácea, glabra, margem revoluta, serreada a partir do terço basal ou do médio, com um par de dentes próximo à base ou dentes ausentes, ápice acuminado a agudo, base aguda a atenuada, face adaxial opaca, nervura primária levemente sulcada a sulcada, secundárias planas, face abaxial sem pontuações ou com pontuações enegrecidas inconspícuas, nervura primária saliente, secundárias levemente salientes. Inflorescência glabra; masculina com flor solitária, raro dicásio com 3 flores, reunidos de 1-4 por axila, pedúnculo ca. 6-10 mm compr.; feminina com flor solitária, raro dicásio com 3 flores, pedúnculo ca. 6-13 $\mathrm{mm}$ compr. Flor 4(-5)-mera; masculina 4-6 mm diam., pedicelo ca. 3-4 mm compr., lobos do cálice arredondados a triangulares, margem não ciliada, estames ca. $2 \mathrm{~mm}$ compr. Fruto 4-5 mm diam., globoso, estigma persistente, inconspícuo; 4 pirenos.

Material examinado: BRASIL. PARANÁ: Adrianópolis, Parque Estadual das Lauráceas, 25-XI-2008 (fr. im.), M.L. Brotto 263 (UPCB); Antonina, Pico Ciririca, 10-X-2010 (fl.), E.D. Lozano 413 (RB); Bocaiúva do Sul, Cerro das Flores, 26-X-1986 (fl.), G. Hatschbach 50806 (K, MBM, NY, UPCB, US); Campina Grande do Sul, Pico Paraná, 5-X-1967 (fl.), G. Hatschbach 17318 (MBM, NY); Colombo, Embrapa, 30III-1987 (fr.), Y.S. Kuniyoshi 5557 (EFC, MBM); Fazenda Rio Grande, Passo Amarelo, 4-XI-2000 (fl.), A. Dunaiski Jr. 1625 (MBM); Guaratuba, Serra de Araçatuba (fl.), A.C. Cervi 6886 (MBM, UPCB); Morretes, Marumbi, 25-XI-2017 (fr. im.), M.L. Brotto 2530 (MBM); Piraquara, Recreio da Serra, 24-X-2013 (fl.), M.L. Brotto 1382 (HCF, MBM); Ibidem,
1-VI-2018 (fr.), M.L. Brotto 2577 (MBM, UEC); Quatro Barras, Morro Anhangava, 7-III-1990 (fr. im.), J.M. Silva 803 (FLOR, MBM, UPCB); São José dos Pinhais, Guaricana, 1-I-1977 (fl.), G. Hatschbach 40257 (MBM, UEC); Tijucas do Sul, Represa Vossoroca, 25-XII-2013 (fr. im.), C.T. Blum 1254 (EFC, MBM).

No Paraná Ilex microdonta é encontrada nas FOD Montana e Altomontana sobre granitos; na FOM Montana sobre migmatitos e na Formação Pioneira com Influência Fluvial do Primeiro Planalto sobre sedimentos recentes, não distando mais do que $40 \mathrm{Km}$ a oeste da Serra do Mar. Ela ocorre entre 900 e 1.850 metros de altitude sendo mais abundante e frequente quanto maior é a altitude (Koehler et al. 2002, Scheer et al. 2011, Scheer \& Blum 2011, Vieira et al. 2014). Ilex microdonta é muito semelhante a Ilex taubertiana, sendo simpátricas em quase toda a área de ocorrência, o que traz certa dificuldade para o reconhecimento desses táxons. Ilex microdonta possui a maioria das folhas obovadas, pecíolo curto (3-8 mm) e inflorescências curtas (6-13 mm), enquanto que I. taubertiana apresenta a maioria das folhas ovadas, pecíolo longo (10-25 mm) e inflorescências longas (13-30 $\mathrm{mm}$ ). Floresce de setembro a dezembro, excepcionalmente em fevereiro, e frutifica de novembro a junho.

9. Ilex paraguariensis A.St.-Hil., Mem. Mus. Parana 9: 351. 1822.

No presente trabalho eu reconheço duas das quatro variedades descritas por Loesener (1901). O fenótipo mais

comum se refere a Ilex paraguariensis A.St.-Hil. var.paraguariensis. O fenótipo menos comumse refere a Ilex paraguariensis var. vestita (Reissek) Loes.

Chave para as variedades de Ilex paraguariensis

1. Ramo jovem, folha e inflorescência glabros, raro pubescentes. 9.1 Ilex paraguariensis var. paraguariensis

1. Ramo jovem, folha e inflorescência hirtelos ou velutinos. 9.2 Ilex paraguariensis

var. vestita

\subsection{Ilex paraguariensis A.St.-Hil. var. paraguariensis}

Figuras 3 a, $5 \mathrm{~b}$

Árvore até $17 \mathrm{~m}$ de alt. Ramo jovem glabro, raro pubescente. Folha com pecíolo 6-13 mm compr., canaliculado, glabro, raro pubescente; lâmina $6-15 \mathrm{~cm} \times 2,3-6,5 \mathrm{~cm}$, proporção 1,8-2,6 × 1, obovada, cartácea a coriácea, glabra, raro pubescente, margem revoluta, crenada a partir do terço basal, crenas terminando em apículos enegrecidos, ápice arredondado a curto-acuminado, base aguda, face adaxial opaca, nervura primária levemente sulcada a plana, secundárias planas a levemente salientes, face abaxial sem pontuações enegrecidas, nervura primária saliente, secundárias levemente salientes. Inflorescência glabra, raro pubescente; masculina em dicásio com 3 flores, raro 7 flores, reunidos 4-9 por axila, pedúnculo 5-10 $\mathrm{mm}$ compr.; feminina em fascículo com 3-9 flores por axila. Flor 4(-5)-mera; masculina 5-6 mm diam., pedicelo 2-6 $\mathrm{mm}$ compr., lobos do cálice arredondados, margem não ciliada, estames 2-2,8 mm compr. Fruto 5-7 mm diam., globoso, sulcado, estigma persistente, conspícuo; 4 pirenos.
Material examinado: BRASIL. PARANÁ: bois prés Curitiba, s.d. (fr.), A. Saint-Hilaire C2-1631 (holótipo - barcode P00631854 [foto!], isótipos - barcodes B 10 0242262 [foto!], NY01365220 [foto!], P00631852 [foto!], P00631853 [foto!], P00631854 [foto!], P02428209 [foto!]); Adrianópolis, Fazenda Mato Limpo, Berneck, 27-X-2005 (fl.), O.S. Ribas 7093 (MBM); Agudos do Sul, VII-1952 (est.), M.J. Nowacki s.n. (MBM 80522); Antônio Olinto, Rio Água Amarela, 8-VIII-1971 (est.), G. Hatschbach 26895 (MBM); Apucarana, Parque da Raposa, 1-X-1999 (bot.), D.A. Estevan 136 (FUEL, SPF); Arapongas, Fazenda Solana, 10VIII-2007, N.S. Cervigne 42440 (FUEL); Araucária, Novo Nordisk, 2-III-1999 (fr.), G. Gatti 328 (UPCB); Bituruna, 13-II-1966 (fr.), G. Hatschbach 13863 (MBM, UPCB); Bocaiúva do Sul, 17-X-1997 (fl.), A.C. Nogueira 13 (EFC); Campina Grande do Sul, Sítio do Belizário, 14-XI-1967 (fr.), G. Hatschbach 17813 (MBM, US); Campo Largo, 19I-1880 (fr.), C.A.W. Schwacke 2468 (RB); Campo Mourão, 13-X-1965 (fl.), G. Hatschbach 12979 (MBM, US); Candói, 19-VII-1971 (fr.), G. Hatschbach 16344 (MBM, UPCB); Capitão Leônidas Marques, UHE Baixo Iguaçu, 18-I-2018 (fr.), J.A. Rocha Filho 528 (UNOP); Carambeí, Catanduva de Fora, 22-IX-2013 (bot.), M.E. Engels 1633 (MBM); Cascavel, Parque Ecológico Paulo Gorski, 12-XII-2007 (fr.), C. Snak 63 (UNOP); Castro, PCH Rio Iapó, 29-X-2016 (fl.), J.M. Silva 9542 (HCF, HUEM, MBM); Catanduvas, 
13-VI-1974 (fr.), G. Hatschbach 34517 (MBM, UEC); Céu Azul, Parque Nacional do Iguaçu, 2-X-2015 (fl.), E.L. Siqueira 6957 (HCF); Clevelândia, 21-XI-1972 (fr. im.), G. Hatschbach 30780 (MBM);Colombo, Embrapa, 30-III-1987 (fr.), Y.S. Kuniyoshi 5550 (EFC, MBM); Contenda, Serrinha, 17-XI-1972 (fl.), G. Hatschbach 30642 (MBM); Corbélia, 22-X-2011 (fl.), S. Segalla s.n. (DVPR 775, HCF 10038); Curitiba, Bosque Martim Lutero, 15-III-2008 (fr.), M.L. Brotto 80 (RB, UPCB); Curiúva, Sítio Carolina, 12-XII-1998 (fr. im.), A.L. Cavalheiro 29 (ESA, FUEL, MBM, UEC); Dois Vizinhos, 21-X-2014 (fl.), E. Duarte 178 (DVPR); Goioerê, parque municipal, 1-V-2005 (fr.), L. Begamasco neto s.n. (HCF 2552); Guarapuava, Campina Redonda, 9-XI-2012 (fr.), M.G. Caxambu 4366 (HCF); Guaratuba, Usina Chaminé, 9-XI-2000 (fl.), E. Barboza 570 (MBM); Imbituva, 21-X-1986 (fl.), Y.S. Kuniyoshi 5069 (EFC, MBM); Irati, Flona, 21-X-1986 (fl.), Y.S. Kuniyoshi 5060 (EFC, MBM); Itaperuçu, 17-XI-1908 (fl.), P.K. Dusén 7076 (NY); Ivaí, Rio Palmital, 8-X-1969 (bot.), G. Hatschbach 22359 (MBM); Lapa, Passa Dois, 2-XI-1955 (fl.), $R$. Braga 33 (HUPG, NY, RB); Laranjeiras do Sul, Rincão Grande, 12-X-1974 (fl.), G. Hatschbach 35210 (MBM, UPCB); Lindoeste, Rio Gonçalves Dias, 1-X-2015 (fr. im.), A.R.Escher 14 (UNOP); Londrina, Parque Municipal Arthur Thomas, 10-XI-2005 (fl.), M.Z. Abrão s.n. (DVPR 923); Luiziana, Estação Ecológica Luiziana, 20-X-2010 (bot.), E.L. Siqueira 371 (HCF); Mallet, 11-III-1927 (est.), L. Gurgel s.n. (RB 111664); Mamborê, 22-IV-2006 (fr.), E.C. Coelho s.n. (HCF); Mandirituba, Colônia Matos, 1-II-2002 (fr.), $A$. Dunaiski Jr. 1788 (UPCB); Mangueirinha, 16-XI-1998 (fl.), G. Hatschbach 68756 (MBM, UPCB); Manoel Ribas, 18X-1973 (bot.), G. Hatschbach 32837 (MBM); Marmeleiro, 21-II-1971 (fr.), G. Hatschbach 26443 (MBM); Matelândia, 3-II-2015 (fr.), R. Cielo-Filho 1600 (MBM, SPSF); Mauá da Serra, Estância Manain, 6-V-2010 (fr.), G.M. Ferreira 205 (FUEL); Medianeira, CTG, 19-XII-2014 (fr.), R. CielloFilho 1610 (DVPR, SPSF); Morretes, Parque Estadual do Pico Marumbi, 23-III-2009 (fl.), M.L. Brotto 325 (UPCB); Ortigueira, Sítio Basílio, 17-X-1999 (fl.), R.A.G. Viani 34 (ESA, FUEL, UPCB); Palmas, Rio Chopim, 16-XI-1998 (fr. im.), G. Hatschbach 68743 (MBM, UPCB); Palmeira, Cantagalo, 31-X-1934 (fl.), L. Gurgel 16130 (RB); Pinhais, Fazenda Canguiri, XI-1985 (fl.), Y.S. Kuniyoshi 4922 (EFC); Pinhão, 15-III-1967 (fr.), J.C. Lindeman 4912 (K, MBM, NY, US); Piraquara, Mananciais da Serra, 21-II-1968 (fr.), G. Hatschbach 18628 (MBM); Pitanga, Rio Bonito, 25-II1971 (fr.), G. Hatschbach 26509 (MBM, UPCB); Ponta Grossa, 13-I-1880 (fr. im.), C.A.W. Schwacke 2467 (RB); Porto Amazonas, s.d., (fr.), L. Gurgel 79 (RB); Prudentópolis, Tijuco Preto, 8-X-2009 (fl.), E. Martins 5 (FUEL, FURB); Quatro Barras, Parque Estadual Serra da Baitaca, 21-X-2008 (fl.), M.L. Brotto 213 (UPCB); Quitandinha, 22-I-1980 (fr.), J.R.S. Muniz s.n. (EFC 50); Rio Azul, 27-XII-1984 (fr. im.), L. Krieger 20045 (ESA); Salgado Filho, 25-V-1972 (fr.), G. Hatschbach 29709 (MBM); Santa Tereza do Oeste, Parque Nacional do Iguaçu, 13-XI-2015 (fr. im.), A.R. Escher 18 (RB, UNOP); Santa Terezinha de Itaipu, Fazenda Santa Maria, 7-II-2012 (fr.), L.G. Temponi 1091 (UNOP); São Jerônimo da Serra, Reserva Indígena São Jerônimo, 15-X-
2002 (fl.), K.L.V.R. de Sá 353 (FUEL); São João do Triunfo, 15-X-1961 (fl.), R. Braga 1706 (UPCB, US); São José dos Pinhais, Rio Una 29-X-1969 (fl.), G. Hatschbach 22734 (MBM, NY); São Mateus do Sul, Lageadinho, 3-II-1977 (fr.), G. Hatschbach 39751 (MBM); Tamarana, Fazenda Prata, 15-XII-1999, R.A.G. Viani 40(FUEL); Teixeira Soares, Fazenda Capão Bonito, 1-VII-1991, M.E. Medri s.n. (FUEL 17318); Telêmaco Borba, Parque Ecológico Klabin, 16-X1999 (fl.), R.A.G. Viani 32 (ESA, FUEL, UEC); Tibagi, Fazenda Batavo, 4-V-1990 (fl.), E. Bianchini s.n. (FUEL 11802, MBM 189350); Tijucas do Sul, Palermo, 4-X-2000 (bot.), E. Barboza 529 (MBM); Tuneiras do Oeste, REBIO das Perobas, 27-X-2011 (bot.), M.G. Caxambu 3619 (HCF); Turvo, propriedade da família Rickli, 18-X-2009 (fl.), M.G. Caxambu 2829 (HCF); União da Vitória, rio Santa Maria, 10-II-1966 (fr.), G. Hatschbach 13841 (MBM, UPCB, US); Ventania, Sítio Santa Laura, 23-II-1999 (fr. im), O.C. Pavão s.n. (FUEL 24831); Vera Cruz do Oeste, 21-IX-2009 (fl.), V.D. Albrecht s.n. (MBM 359504).

Material adicional examinado: BRASIL.SÃo PAULO: s.d. (fl.), F. Sellow 2032/2080 (sintipo de Ilex domestica var. glabra Reissek - barcode K000588520[foto!]).

No Paraná Ilex paraguariensis var. paraguariensis é encontrada na FOD Montana, na FOM e na FES, entre 280 e $1.250 \mathrm{~m}$ de altitude. Na região da Serra do Mar ela ocorre acima dos $800 \mathrm{~m}$ onde apresenta frequência mediana. $\mathrm{Na}$ Floresta Estacional ela é registrada apenas nas regiões de Londrina e do Parque Nacional do Iguaçu, sendo pouco comum em ambas. Por sua vez, ela é amplamente distribuída nos planaltos acima dos $800 \mathrm{~m}$ de altitude, coincidindo com a zona da FOM, sendo comum na maior parte dessa unidade fitogeográfica. Portanto, ela ocorre sobre uma variedade de rochas ígneas, metamórficas e sedimentares. Ilex paraguariensis var. paraguariensis é semelhante à Ilex dumosa, a qual possui folhas elípticas com pecíolo menor. Difere da variedade vestita pelos ramos, folhas e inflorescências glabras. Floresce de setembro a dezembro com concentração de outubro a novembro, mas também em janeiro, fevereiro, março, abril e julho, frutifica de outubro a julho.

9.2 Ilex paraguariensis var. vestita (Reissek) Loes., Nova Acta Acad. Caes. Leop.-Carol. German. Nat. Cur. 78: 309. 1901.

\section{Figuras $3 \mathrm{~b}, 5 \mathrm{c}$}

Árvore até $8 \mathrm{~m}$ de alt. Ramo jovem hirtelo ou velutino. Folha com pecíolo 5-10 mm compr., canaliculado, hirtelo a velutino; lâmina 4,5-10 cm × 1,8-4 cm, proporção 1,7-2,5 $\times$ 1 , obovada, cartácea a coriácea, hirtela a velutina, margem revoluta, crenada a partir do terço basal, crenas terminando em apículos enegrecidos, ápice arredondado acurtoacuminado, base aguda, face adaxial opaca, nervuras planas, face abaxial sem pontuações enegrecidas, nervura primária saliente, secundárias levemente salientes.Inflorescência hirtela a velutina; masculina em dicásio com 3 flores, reunidos 4-5 por axila, pedúnculo 2-4 mm compr.; feminina em fascículo com 3-8 flores por axila. Flor 4-mera; masculina ca. $6 \mathrm{~mm}$ diam., pedicelo 2-3 mm compr., lobos do cálice arredondados, margem ciliada, estames 2,3-2,5 mm compr. 
Fruto (maduro não visto), globoso, estigma persistente, conspícuo; 4 pirenos.

Material examinado: BRASIL. PARAná: s.d. (fr.), $F$. Sellow 4242/4756 (possível tipo de Ilex vestita Reissek - barcodes B 101130455 [foto!], K000588524 [foto!], K000588526 [foto!], S14-19998 [foto!]); Campo Largo, Colônia Weitmarsum, 22-X-1965 (fl.), G. Hatschbach 13054 (MBM, US); Jaguariaíva, Fazenda Cajuru, 13-X-1968 (fl.), G. Hatschbach 20052 (MBM, US); Lapa, Passa Dois, 2-XI1955 (fl.), R. Braga 34 (FUEL, MBM, UPCB, US, RB); Palmeira, Cantagalo, 31-X-1931 (fr. im.), L. Gurgel 16144 (RB); sem município, Serrinha, 22-X-1908 (fl.), P.K. Dusén 6935 (K, NY); Ponta Grossa, Rio São Jorge, 6-XI-1992 (fr.), D. Schiesinsky 150 (FUEL, HUEM, UPCB).

No Paraná Ilex paraguariensis var. vestita é encontrada apenas FOM do Segundo Planalto sobre rochas dos Grupos Itararé e Paraná entre 850 e $1.100 \mathrm{~m}$ de altitude. Ela é amplamente distribuída na porção oriental do Segundo Planalto embora seja pouco comum. Inclusive, as duas variedades são simpátricas nessa região. Difere da variedade paraguariensis principalmente pelo indumento hirtelo a velutino. Floresce de outubro a novembro e frutifica de outubro a dezembro.

10. Ilex pseudobuxus Reissek in Mart., Fl. Bras. 11(1): 40. 1861.

Figuras 3 c-e, 4 b

Arbusto ou árvore até $8 \mathrm{~m}$ de alt. Ramo jovem glabro. Folha com pecíolo 2-5 mm compr., canaliculado, glabrescente; lâmina 2-6,5 × 1-3,1 cm, proporção $2 \times 1$, obovada, cartácea a coriácea, glabra, margem revoluta em toda a extensão, inteira ou com poucos dentes na metade apical, um par de dentes próximo à base, ápice arredondado, raro obtuso ou retuso, base cuneada a aguda, face adaxial pouco lustrosa, nervura primária levemente levemente sulcada, raro plana, secundárias planas, face abaxial sem pontuações, nervura primária saliente, secundárias levemente salientes. Inflorescência glabra, raro glabrescente; masculina e feminina em dicásio com 3 flores, solitário, pedúnculo 6-25 mm compr. Flor 4-mera; masculina ca. $4 \mathrm{~mm}$ diam., pedicelo 1-3 mm compr., lobos do cálice triangulares, margem não ciliada, estames ca. $2 \mathrm{~mm}$ compr. Fruto 4-6 mm diam., globoso, estigma persistente, inconspícuo; 4 pirenos.

Material examinado: BRASIL. PARANÁ: Guaraqueçaba, Parque Nacional de Superagui, V-2003 (fr.), L.D. Meireles 1436 (UEC); Guaratuba, rio Boguassu, 11-XII-1957 (fl.), G. Hatschbach 4300 (MBM, US); Matinhos, 25-III-1995 (fr.), O.S. Ribas 808 (FLOR, K, MBM, RB); Morretes, Jacarehý, 2-XII-1909 (fl.), P.K. Dusén 8646 (K, NY); Paranaguá, Piaçaguera, 23-IV-1969 (fr.), G. Hatschbach 21411 (K, MBM); Ibidem, rio Guaraguaçu, 8-XII-1986 (fl.), Y.S. Kuniyoshi 5150 (K, MBM); Pontal do Paraná, Praia de Leste, 20-XII-1964 (fl.), G. Hatschbach 12052 (MBM).

No Paraná Ilex pseudobuxus é encontrada nas FOD das Terras Baixas e Aluvial e nas Formações Pioneiras com Influência Fluvial e Marinha entre 2 e 50 metros de altitude. É amplamente distribuída na Planície Litorânea ocorrendo exclusivamente sobre sedimentos inconsolidados do Cenozóico. Nessa região ela é simpátrica com Ilex theezans, da qual pode ser facilmente diferenciada por características de inflorescência, flor e fruto ou pelo tamanho das folhas.
Floresce de novembro a janeiro e em março, frutifica de janeiro a maio.

11. Ilex taubertiana Loes. in Engl. \& Prantl, Nat. Pflanzenfam. Nachtr. 1: 218. 1897.

Figuras 3 f-g, 5 c

Árvore até $15 \mathrm{~m}$ de alt. Ramo jovem glabrescente. Folha com pecíolo 10-25 mm compr., canaliculado, glabro; lâmina 3,7-8 cm × 1,7-2,8 cm, proporção 2-2,8 $\times 1$, ovada a elíptico-ovada, cartácea, glabra, margem revoluta, serreada a partir do terço basal, um par de dentes próximo à base, ápice acuminado a agudo, base aguda a atenuada, face adaxial opaca, nervura primária levemente sulcada a sulcada, secundárias planas, face abaxial com pontuações enegrecidas, nervura primária saliente, secundárias levemente salientes. Inflorescência glabrescente a pubérula; masculina em dicásio com 3 flores, raro 7 flores, um por axila, pedúnculo 13-30 mm compr.; femininas não vistas. Flor 4-mera; masculina 4-5 mm diam., pedicelo 3-10 mm compr., lobos do cálice triangulares, margem não ciliada, estames 2-2,2 mm compr. Fruto 4-5 mm diam., globoso, estigma persistente, conspícuo; 4 pirenos.

Material examinado: BRASIL. PARANÁ: Adrianópolis, Parque Estadual das Lauráceas, 26-X-2015 (fl.), M.L. Brotto 2096 (EFC, MBM, RB); Balsa Nova, Serra Santana, 18-IV1969 (fr.), G. Hatschbach 21348 (FLOR, K, MBM, NY, RB, UPCB); Bocaiúva do Sul, Sesmaria, 29-I-1969 (fr.), G. Hatschbach 20943 (MBM, NY, UEC); Campina Grande do Sul, trilha até o morro Getúlio, 8-II-2014 (fl.), R.R. Völtz 678 (EFC); Guaraqueçaba, RPPN Salto Morato, 18-VII-2013 (fr. im.), M.L. Brotto 1318 (MBM, RB); Guaratuba, Serra de Araçatuba, 13-XI-1998 (fl.), E.P. Santos 593 (MBM, NY, UPCB); Morretes, Véu de Noiva, 7-I-1951 (fl.), G. Hatschbach 2083 (MBM, US); Palmeira, Fazenda Santa Rita, 3-XII-1981 (fl.), G. Hatschbach 44450 (MBM, NY); Piraí do Sul, Fazenda Nova Era, 15-II-2013 (fr. im.), M.L. Brotto 952 (MBM, RB, UNOP); Piraquara, Mananciais da Serra, 19-IV2008 (fr. im.), M.G. Caxambu 2075 (FUEL, HCF, MBM); Quatro Barras, rio do Corvo, 23-XI-1988 (fl.), G. Hatschbach 52533 (FLOR, K, UPCB, US); São José dos Pinhais, Zinco, 11-XI-1982 (fl.), R. Kummrow 2081 (K, MBM, SP, US); Tijucas do Sul, Pico Araçatuba, 15-VII-2007 (fr. im.), M.L. Brotto 37 (UPCB); Tunas do Paraná, Parque Estadual de Campinhos, 3-IV-2011 (fr. im.), M.L. Brotto 600 (UPCB).

No Paraná Ilex taubertiana é encontrada nas FOD Montana e Altomontana sobre granitos, bem como na FOM Montana do Primeiro Planalto sobre rochas ígneas e metamórficas, e na "cuesta" do Segundo Planalto sobre o Arenito Furnas, entre 890 e 1.300 metros de altitude. Dentre as espécies estudadas se assemelha Ilex microdonta e a Ilex brevicuspis, sendo simpátrica às duas. Difere da primeira pela forma da lâmina geralmente ovada e pelo maior comprimento dos pecíolos e inflorescências, enquanto que da segunda difere principalmente pela margem nitidamente serreada. Floresce de outubro a janeiro e frutifica de novembro a julho.

12. Ilex theezans Mart. ex Reissek in Mart., Fl. Bras. 11(1): 51. 1861 .

Figuras 3 h-k, 5 d

Arbusto ou árvore até $20 \mathrm{~m}$ de alt. Ramo jovem glabro. Folha com pecíolo 7-45 mm compr., canaliculado, em geral 


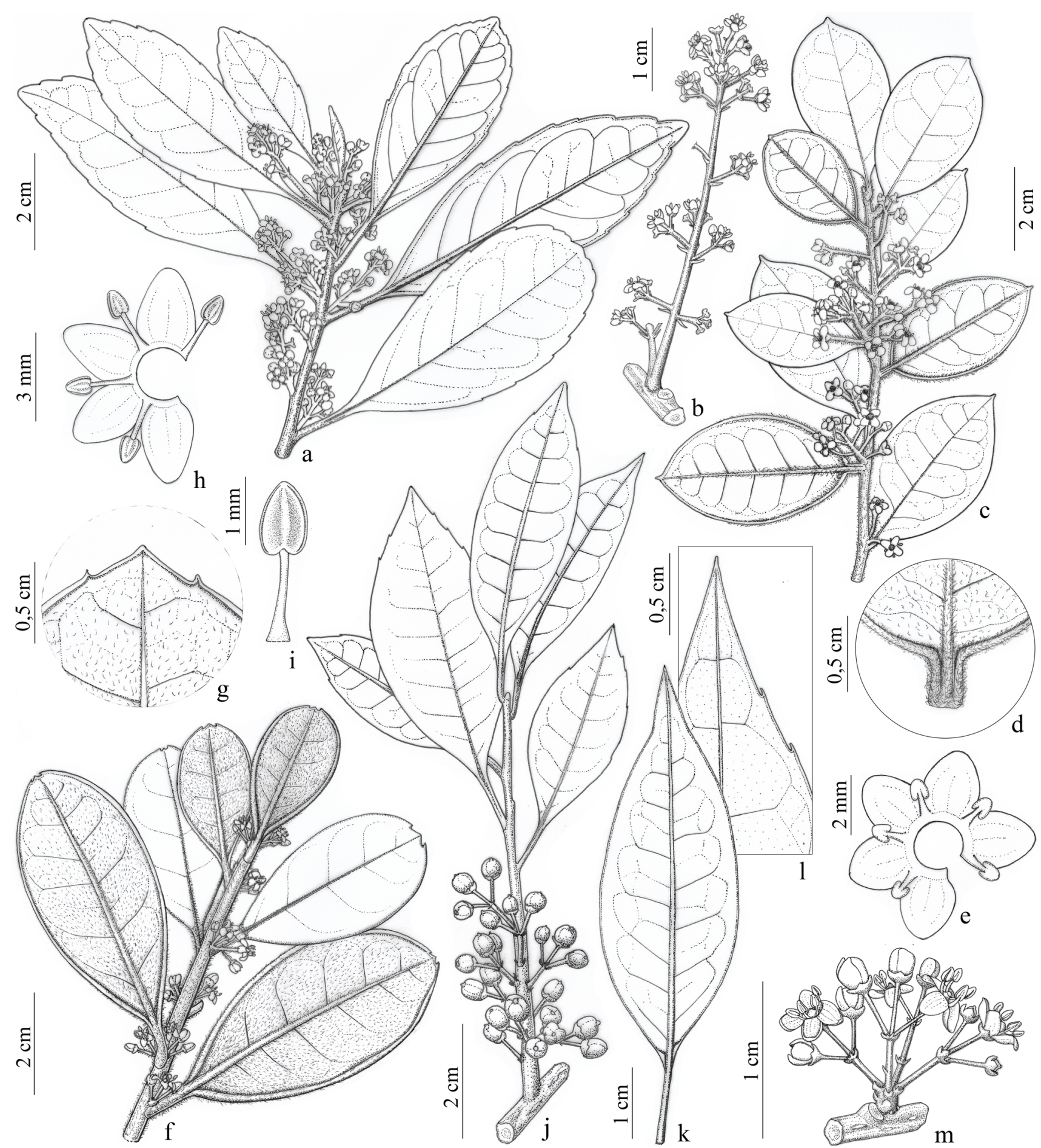

Figura 1. Ilex affinis Gardner. a. ramo com flores. b. inflorescência masculina (tirso). Ilex asperula Mart. ex Reissek. c. ramo com flores. d. detalhe da base da folha (face abaxial). e. corola e estaminódios de flor feminina. Ilex brasiliensis (Spreng.) Loes.. f. ramo com flores masculinas. g. detalhe do ápice da folha (face abaxial). h. corola e estames de flor masculina. i. estame. Ilex brevicuspis Reissek. j. ramo com frutos. k. face abaxial de folha com margem inteira. 1. detalhe da margem denteada da folha. m. inflorescências masculinas (aglomerado de dicásios). (a. G. Hatschbach 15780; b. J. Carneiro 144; c-e. G. Hatschbach 5069; f-i. G. Hatschbach 19999; j. 1. J.M. Silva 939; k. J.M. Silva 823; m. G. Hatschbach 15395).

Figure 1. Ilex affinis Gardner. a. branch with flowers. b. male inflorescence (thyrse). Ilex asperula Mart. ex Reissek. c. branch with flowers. d. leaf base detail (abaxial surface). e. corolla and staminodes of female flower. Ilex brasiliensis (Spreng.) Loes.. f. branch with male flowers. g. leaf apex detail (abaxial surface). h. corolla and stamens of male flower. i. stamen. Ilex brevicuspis Reissek. j. branch with fruits. k. abaxial surface of leaf with entire margin. 1. dentate leaf margin detail. m. male inflorescences (cluster of dichasia). 


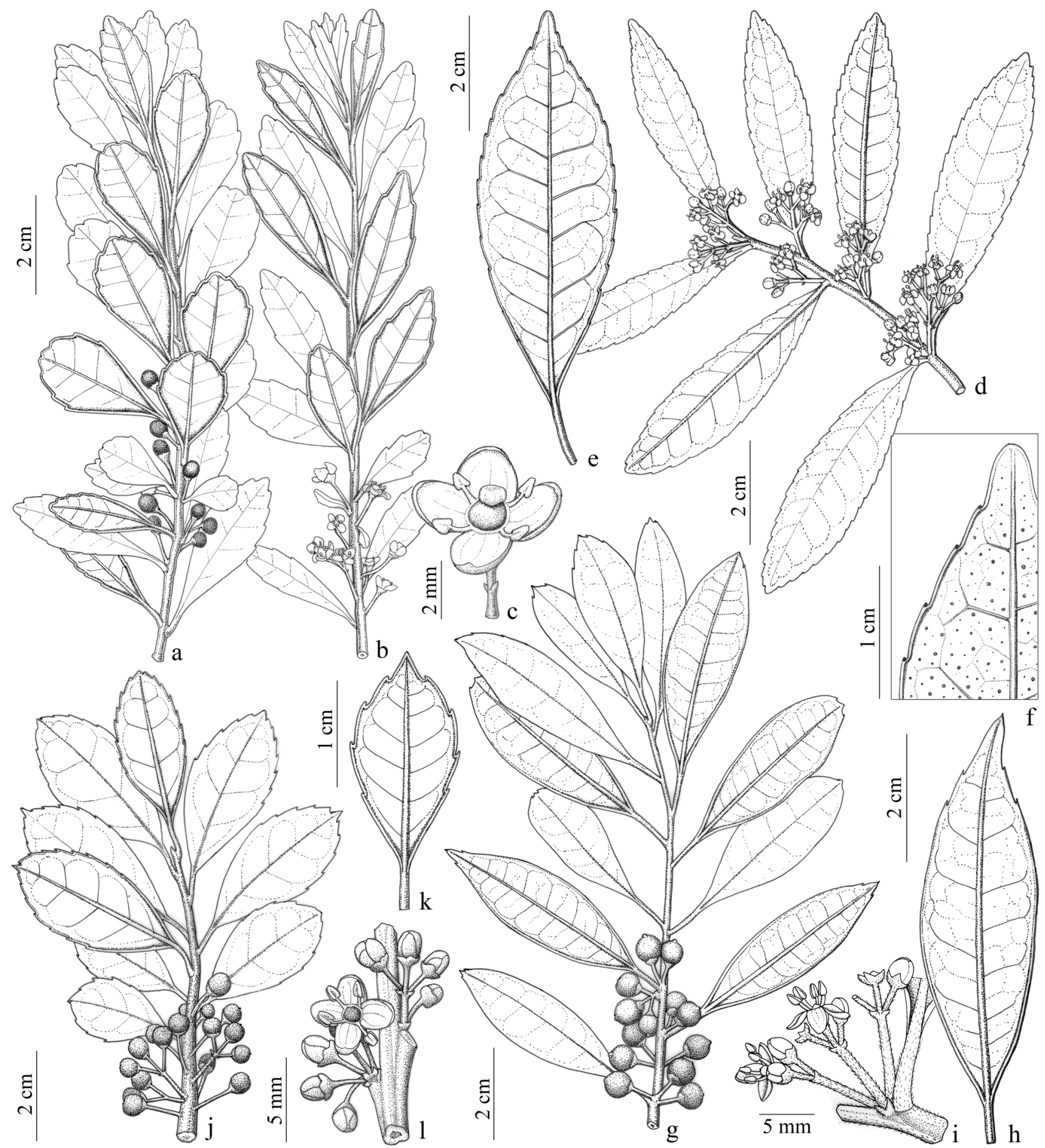

Figura 2. Ilex chamaedryfolia Reissek. a. ramo com frutos. b. ramo com flores. c. flor feminina. Ilex dumosa Reissek. d. ramo com flores masculinas. e. face abaxial da folha. f. detalhe da face abaxial da folha com glândulas e apículos enegrecidos. Ilex gracilior (Warmg.) Brotto. g. ramo com frutos. h. face abaxial da folha. i. inflorescências masculinas. Ilex microdonta Reissek. j. ramo com frutos. k. face abaxial da folha. 1. inflorescências masculinas (flores solitárias e dicásio). (a. G. Hatschbach 14558; b-c. A.C. Cervi 3014; d. G. Hatschbach 22858; e-f. G. Hatschbach 25637; g-i. M.L. Brotto 3706; j. M.L. Brotto 2577; k. J.M. Silva 803; 1. M.L. Brotto 1382).

Figure 2. Ilex chamaedryfolia Reissek. a. branch with fruits. b. branch with flowers. c. female flower. Ilex dumosa Reissek. d. branch with male flowers. e. abaxial leaf surface. f. detail of the abaxial leaf surface with glands and blackened apiculum. Ilex gracilior (Warmg.) Brotto. g. branch with fruits. h. abaxial leaf surface. i. male inflorescences. Ilex microdonta Reissek. j. branch with fruits. k. abaxial leaf surface. 1. male inflorescences (singleflowers and dichasium). 


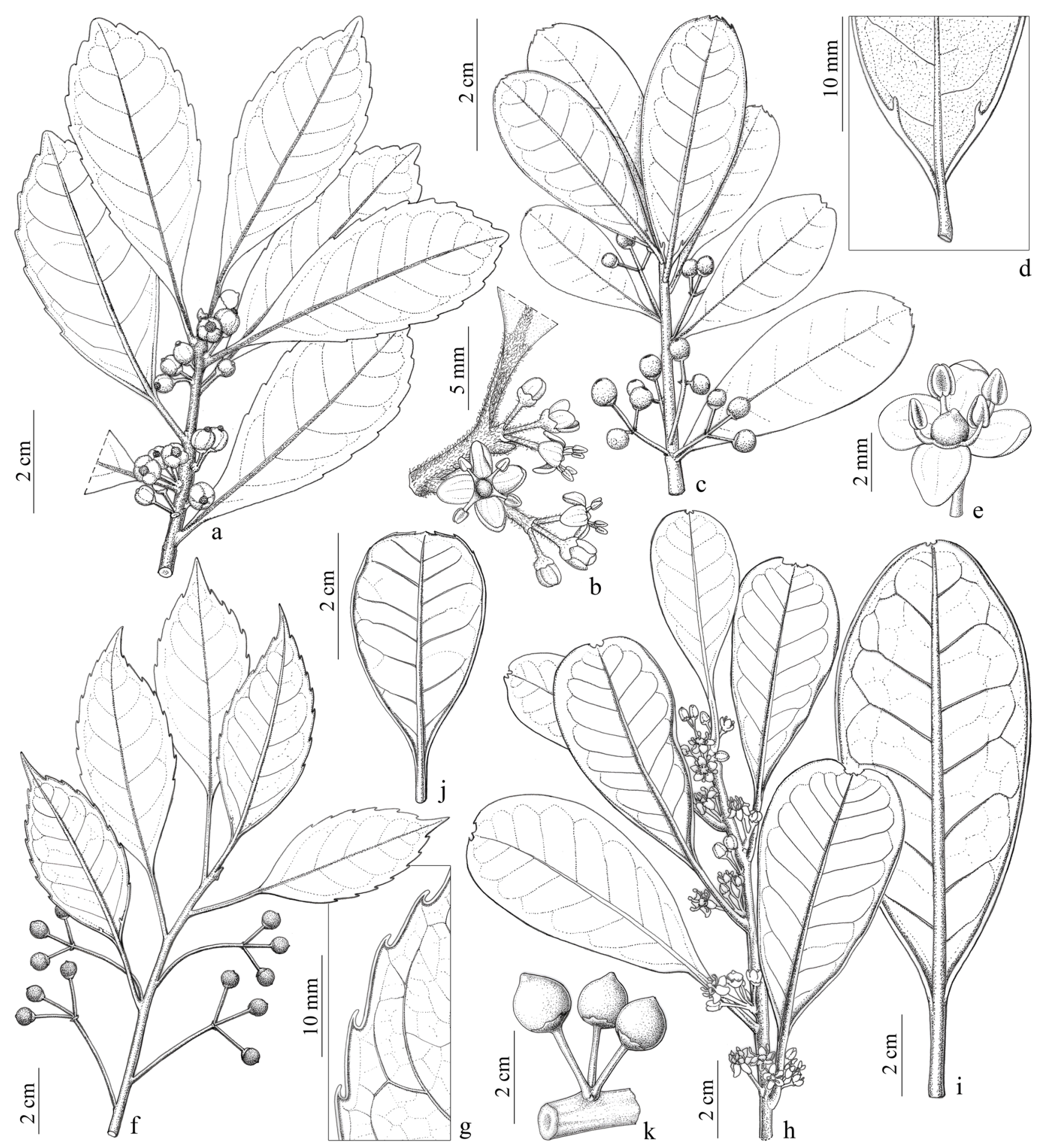

Figura 3. Ilex paraguariensis A.St-Hil. var. paraguariensis. a. ramo com frutos. Ilex paraguariensis var. vestita (Reissek) Loes. b. inflorescências masculinas (flores solitárias e dicásio). Ilex pseudobuxus Reissek. c. ramo com frutos. d. detalhe da base da folha (face abaxial). e. flor masculina. Ilex taubertiana Loes. f. ramo com frutos. g. detalhe da margem serreada (face abaxial). Ilex theezans Mart. ex Reissek. h. ramo com flores masculinas. i. face abaxial da folha. j. face abaxial da folha. k. frutos. (a. G. Hatschbach 18628 ; b. G. Hatschbach 20052; c-d. G. Hatschbach 21411; e. Y.S. Kuniyoshi 5150; f-g. M.G. Caxambu 2075; h. G. Hatschbach 22785; i. M.L. Brotto 3705; j. M.L. Brotto 4025; k. J.M. Silva 8605).

Figure 3. Ilex paraguariensis A.St-Hil. var. paraguariensis. a. branch with fruits. Ilex paraguariensis var. vestita (Reissek) Loes. b. male inflorescences (singleflowers and dichasium). Ilex pseudobuxus Reissek. c. branch with fruits. d. leaf base detail (abaxial surface). e. male flower. Ilex taubertiana Loes. f. branch with fruits. g. serrate leaf margin detail (abaxial surface). Ilex theezans Mart. ex Reissek. h. branch with male flowers. i. abaxial leaf surface. j. abaxial leaf surface. k. fruits. 


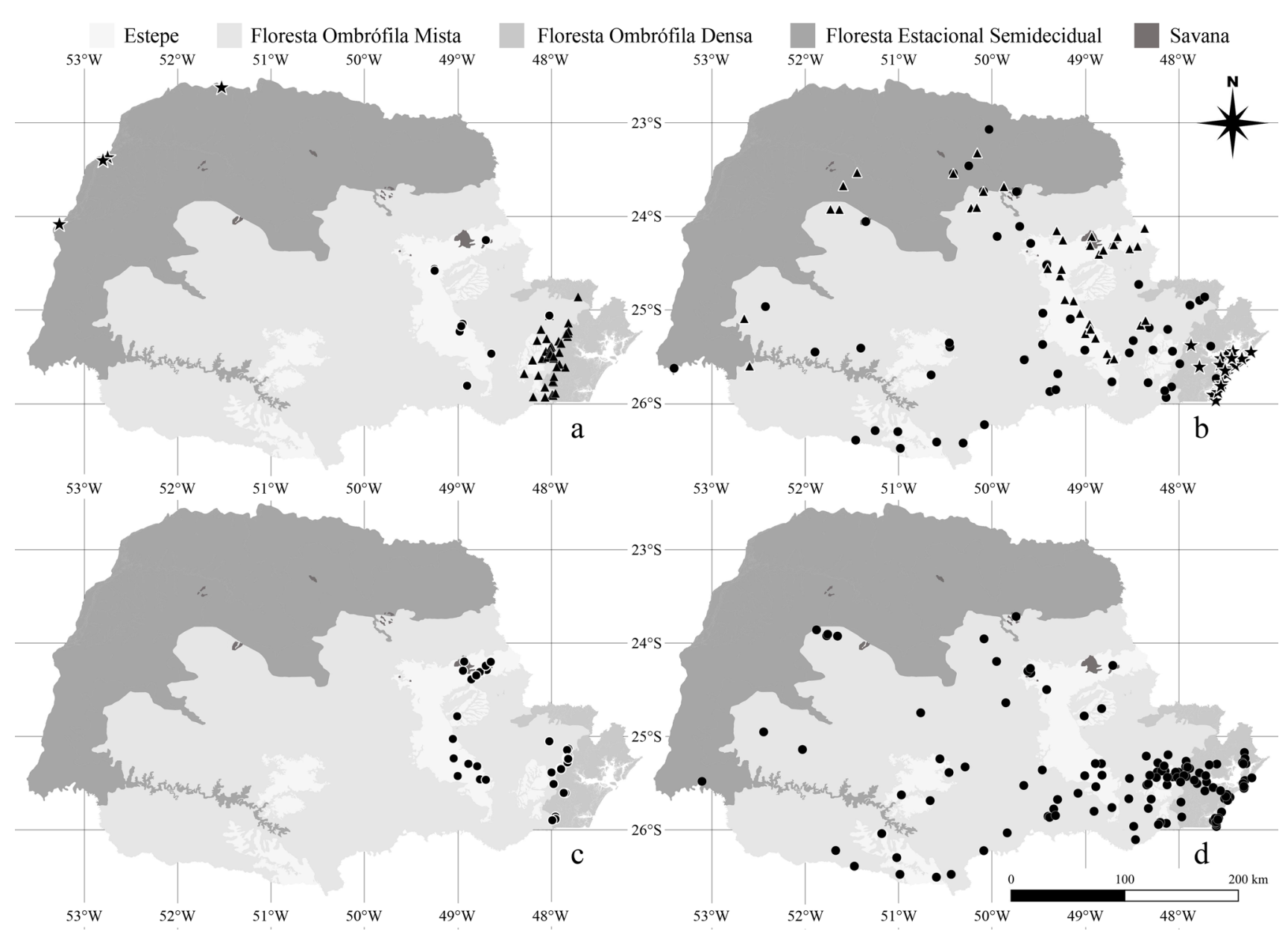

Figura 4. Mapas da distribuição das espécies de Aquifoliaceae no Estado do Paraná, Brasil. a. Ilex affinis (estrela), Ilex asperula (ponto), Ilex microdonta (triângulo). b. Ilex brasiliensis (triângulo), Ilex brevicuspis (ponto), Ilex pseudobuxus (estrela). c. Ilex chamaedryfolia (ponto). d. Ilex dumosa (ponto).

Figure 4. Distribution maps of Aquifoliaceae species in Paraná State, Brazil. a. Ilex affinis (star), Ilex asperula (dot), Ilex microdonta (triangle). b. Ilex brasiliensis (triangle), Ilex brevicuspis (dot), Ilex pseudobuxus (star). c. Ilex chamaedryfolia (dot). d. Ilex dumosa (dot).

rugoso, glabro, 1,5-3 mm esp.; lâmina 4-15 × 1,5-7 cm, proporção 1,8-3,6 × 1, obovada a oblonga, raro elíptica, frequentemente assimétrica, coriácea, glabra, margem fortemente revoluta ou apenas revoluta, inteira ou com poucos dentes na metade apical, ápice retuso a obtuso, às vezes com um apículo muito curto, raro agudo, base aguda a atenuada, face adaxial opaca, nervura primária sulcada, raro plana, secundárias planas a levemente salientes, face abaxial sem pontuações, nervura primária saliente, secundárias levemente salientes, ângulo de $35^{\circ}-75^{\circ} \mathrm{em}$ relação à primária. Inflorescência glabra; masculina em dicásio com 3 flores, raro 5 flores, reunidos de 4-12 por axila, pedúnculo 1-10 mm compr.; feminina em fascículo com 4-8 flores por axila. Flor 4 (-5)-mera; masculina 7-10 mm diam., pedicelo 2-5 mm compr., lobos do cálice arredondados a triangulares, glabros, margem não ciliada, estames 3-4 mm compr. Fruto 9-13 mm diam., ovoide, globoso, raro elipsoide, estigma persistente, conspícuo; 4-5 pirenos.

Material examinado: BRASIL. PARANÁ: Adrianópolis, Parque Estadual das Lauráceas, 26-X-2015 (fl.), M.L. Brotto 2094 (EFC, MBM, RB); Agudos do Sul, Lagoinha, 8-XI-1989 (fl.), G. Hatschbach 53596(K, MBM); Almirante Tamandaré, morro próximo à cidade, 15-X-2020 (fl.), M.L. Brotto 4001 (BHCB, CESJ, ESA, MBM, RB); Antonina, Rio Xaxim, 19-XI-1998 (fl.), G. Hatschbach 68832 (MBM, RB, UPCB); Balsa Nova, Serra Santana, 1-XI-1969 (fl.), G. Hatschbach 22785 (MBM); Bituruna, Fazenda Lageado Grande, 30-X2007 (fl.), D. Liebsch 1326 (MBM); Bocaiúva do Sul, Serra da Bocaina, 16-I-2001 (fr.), O.S. Ribas 3162 (K, MBM, RB); Campina Grande do Sul, Morro Camapuã, 24-X-2000 (fl.), J. Cordeiro 1786 (FLOR, HCF, K, MBM, RB); Campo do Tenente, 25-I-1968 (fr.), G. Hatschbach 18478 (MBM); Campo Largo, 3-X-1958 (fl.), G. Hatschbach 5081 (MBM, UPCB, US); Carambeí, Catanduva de Fora, 15-X-2013 (fl.), M.E. Engels 1778 (MBM, UNOP); Castro, PCH Rio Iapó, 28-X-2016 (fr. im.), J.M. Silva 9528 (HUEM, MBM); Cerro Azul, Rio Turvo, 5-X-1977 (fl.), G. Hatschbach 40326 (MBM, NY, UEC); Clevelândia, Granja Palmar, 5-III-1991 (fr. im.), S.D. Prat Kricun s.n. (MBM 261950); Colombo, Embrapa, 9-XI-1986(fl.), Y.S. Kuniyoshi 5142 (EFC, MBM); Curitiba, Parque Barigui, 3-IX-1963 (fl.), L.T. Dombrowski 5018 (MBM); Curiúva, Fazenda São José, 24-XI-1999 


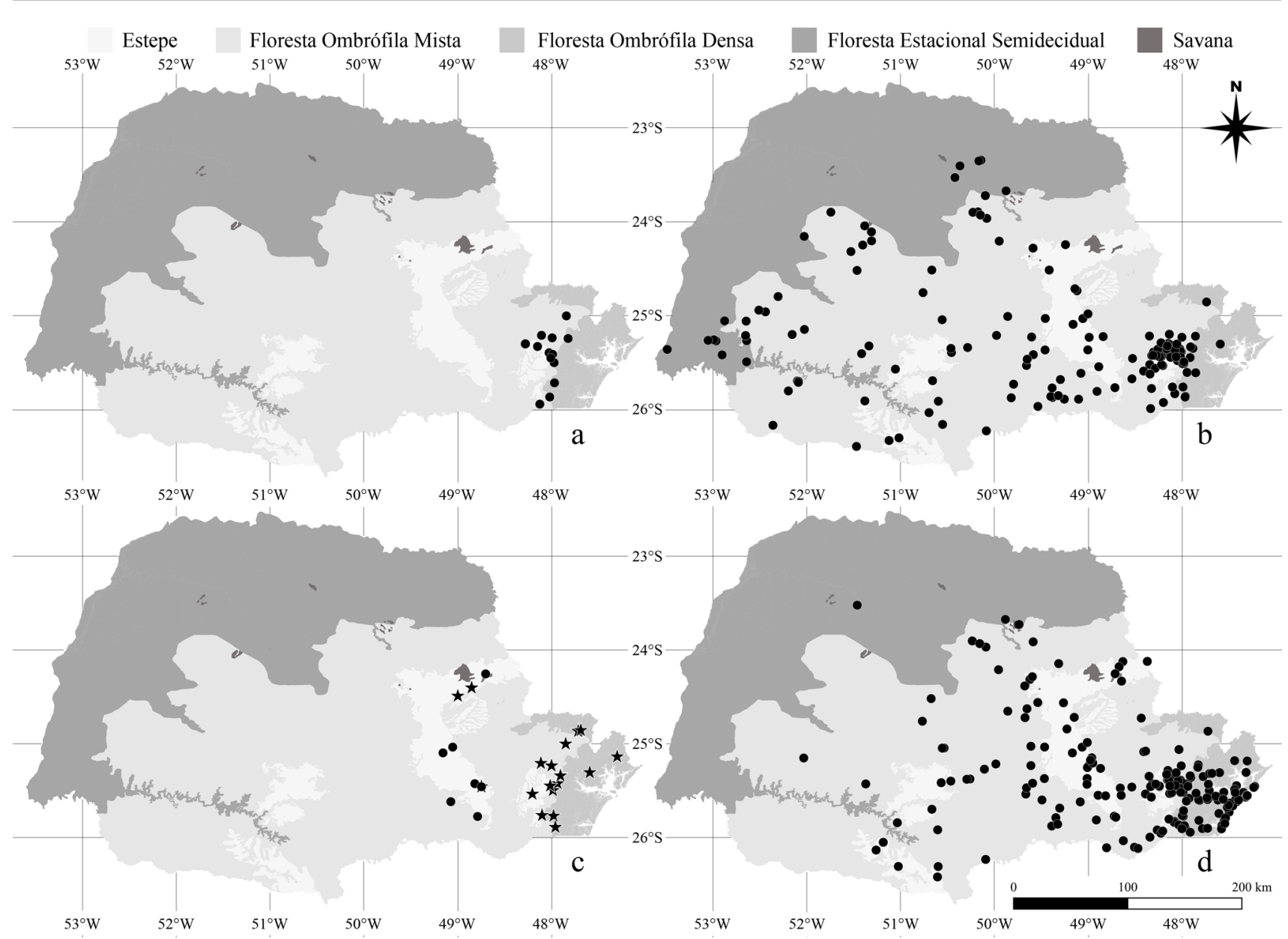

Figura 5. Mapas da distribuição das espécies de Aquifoliaceae no Estado do Paraná, Brasil. a. Ilex gracilior (ponto). b. Ilex paraguariensis var. paraguariensis (ponto). c. Ilex paraguariensis var. vestita (ponto), Ilex taubertiana (estrela). d. Ilex theezans (ponto). Figure 5. Distribution maps of Aquifoliaceae species in Paraná State, Brazil. a. Ilex gracilior (dot). B. Ilex paraguariensis var. paraguariensis (dot). c. Ilex paraguariensis var. vestita (dot), Ilex taubertiana (star). d. Ilex theezans (dot).

(fl.), O.C. Pavão s.n. (FUEL 27791); Doutor Ulysses, Rio Turvo, 2-II-1999 (fr.), G. Hatschbach 69817 (FUEL, K, MBM); Fernandes Pinheiro, Bituva dos Lúcios, 5-IX-2015 (fr.), B. Pereira s.n. (DVPR 2601); Guarapuava, Serra da Esperança, 20-X-1960 (fl.), G. Hatschbach 7391 (MBM, US); Guaraqueçaba, Barra de Superaguí,16-XI-2013 (fl.), M.L. Brotto 1420 (HCF, MBM); Guaratuba, Descoberto, 12VIII-2014 (fr.), J.M. Silva 8605 (EFC, FLOR, FURB, HCF, MBM, RB); Imbituva, 23-III-1987 (fr. im.), Y.S. Kuniyoshi 5553 (EFC, MBM); Ipiranga, Rio Capivari, 8-X-1969 (fl.), G. Hatschbach 22351 (K, MBM); Irati, Flona, 24-III-1987 (fr.), Y.S. Kuniyoshi 5556(K, MBM); Jaguariaíva, 23-II-1915 (fr.), P.K. Dusén 16722 (K, P); Lapa, RPPN Mata do Uru, 5-XI-2020 (fl.), M.L. Brotto 4025 (BHCB, ESA, K, MBM, NY, RB); Laranjeiras do Sul, Faxinal Grande, 24-X-1975 (fl.), G. Hatschbach 37346 (MBM); Mangueirinha, PCH Tigre, 14-XI-2016 (fl.), J.M. Silva 9632 (HCF, MBM); Manoel Ribas, 18-X-1973 (fl.), G. Hatschbach 32844 (K, MBM); Marmeleiro, 25-X-1969 (fl.), G. Hatschbach 22663 (MBM); Matinhos, 2-XI-1949 (fl.), G. Hatschbach 1578 (MBM, UEC); Mauá da Serra, Estância Manain, 10-VI-2008 (fr.), V.M. Cotarelli 163(FUEL, HCF); Morretes, Jacarehý, 17-III-1909 (fr.), P.K. Dusén 7851 (K, P); Ortigueira, Morro da Pedra Branca, 17-X-2014 (fl.), M.G. Caxambu 5612 (HCF, MBM); Palmas, Fazenda São Geraldo, 17-IV-1987 (fr.), J.T. Motta 846 (MBM); Palmeira, Serra das Almas, 12-I-1966 (fr.), G. Hatschbach 13484 (MBM, UPCB, US); Paranaguá, Reserva Biológica do Guaraguaçu, 10-X-1986 (fl.), Y.S. Kuniyoshi 5025 (EFC, K, MBM); Piên, Poço Frio, 6-X-1987 (fl.), G. Hatschbach 51484 (K, MBM, UPCB); Pinhais, Fazenda Experimental de Agronomia, 21-X-1970 (fl.), N. Imaguire 2571 (HCF, MBM); Pinhão, Salto Fazenda Reserva, 24-II-1996 (fr.), G. Hatschbach 64522(EFC, K); Piraí do Sul, X-1980 (fl.), L.T. Dombrowski s.n. (MBM 179621); Piraquara, Recreio da Serra, 9-II-2020 (fr. im.), M.L. Brotto 3705 (EFC, ESA, FLOR, HCF, HUPG, MBM, RB); Pitanga, Pedreira São Judas Tadeu, 24-X-2008 (fl.), A.E. Bianek 332 (HCF); Ponta Grossa, Parque Estadual de Vila Velha, 14-IV-1992 (fr.), A.C. Cervi 3671 (FLOR, MBM, UPCB); Pontal do Paraná, Pontal do Sul, 24-X-1978 (fl.), G. Hatschbach 41743 (MBM); Porto Amazonas, Fazenda São Luiz, 13-X-1963 (fl.), G. Hatschbach 11075 (MBM, UPCB); Prudentópolis, Rio das Pedras, 5-XI-1911 (fr.), P.K. Dusén 11063 (K); Quatro Barras, Morro Anhangava, 12-I-1994 (fr.), C.V. Roderjan 75 (EFC); Reserva, 19-II-1999 (fr.), E.M. Francisco s.n. (FUEL 23285); Reserva do Iguaçu, Fazenda Reserva, 7-III-1967 (fr.), J.C. Lindeman 4702 (K, NY); Rio Branco do Sul, Serra do Bromado, 6-III-1990 (fr.), J.M. Silva 799 (ESA, FLOR, K, MBM); Rio Negro, Pangaré, 16-X-1958 (fl.), G. Hatschbach 5146 (MBM); São 
Jerônimo da Serra, Reserva Indígena São Jerônimo, 29-XI2002 (fr. im.), K.L.V.R. de Sá 410 (FUEL, MBM, UEC); São João do Triunfo, Fazenda São João, 22-VII-1966 (est.), J.C. Lindeman 1906 (MBM, RB); São José dos Pinhais, Rio Pequeno, 2-XI-2004 (fl.), J.M.Silva 4190 (FUEL, FURB, HUCP, MBM, RB); São Mateus do Sul, Fazenda do Durgo, 24-II-1987 (fr.), R.M. Britez 1317 (MBM, UEC, UPCB); São Tomé, Fazenda Lagoa, 3-IV-1966 (fr.), J.C. Lindeman 873 (K, NY); Sapopema, 15-X-1998 (fl.), E.M. Francisco s.n. (DVPR 803, HUEM 5326, FUEL 22367); Sengés, PCH Fazenda Entre Rios, 26-III-2016 (fr.), J.M. Silva 9263 (HCF, MBM); Teixeira Soares, Fazenda Capão Bonito, 1-VII-1991, E.P.Fonseca s.n. (FUEL 17322); Telêmaco Borba, 17-X-1999 (fl.), R.A.G. Viani 24 (FUEL, MBM, SPF); Tibagi, Guartelá, 10-X-1992 (fl.), G. Hatschbach 58205 (FUEL, MBM, RB); Tijucas do Sul, Saltinho, 2-IV-1987 (fr.), G. Hatschbach 50880 (K, MBM, US); Turvo, propriedade da família Rickli, 18-X-2009 (fl.), M.G. Caxambu 2810 (ALCB, FURB, HCF, UPCB); União da Vitória, Rio Iguaçu, 1-XI-1970 (fl.), $C$. Koczicki 266 (MBM); Ventania, Fazenda Califórnia, 4-VI2004 (fr.), D.A. Estevan 395 (FUEL, SPF).

No Paraná Ilex theezans é encontrada na FOD, na FOM, nas Formações Pioneiras com Influência Marinha (restinga) e Fluvial (várzea), e no Refúgio Vegetacional Altomontano (campo de altitude) ocorrendo sobre uma variedade de rochas ígneas, metamórficas e sedimentares. Ela é amplamente distribuída na área de ocupação dessas fitofisionomias sendo especialmente abundante na restinga (Ziller et al. 1999). Neste hábitat Ilex theezans é simpátrica com Ilex pseudobuxus que também possui folhas obovadas, porém menores. As duas se diferenciam pelo arranjo das inflorescências, tamanho das flores e estames, além do aspecto do estigma nos frutos. Em ambientes de solo raso e grande altitude Ilex theezans tende a apresentar folhas pequenas e obovadas, exibindo semelhança com Ilex gracilior. Floresce de setembro a dezembro com concentração de outubro a novembro, mas também em janeiro, abril e julho, frutifica de setembro a agosto com concentração entre fevereiro e abril.

Nos materiais analisados foi possível reconhecer fenótipos que se enquadram em alguns dos 13 táxons infraespecíficos publicados por Loesener (1901), mas também em Ilex integerrima (Vell.) Reissek e em Ilex psammophila Mart. ex Reissek. Apesar disso, o polimorfismo foliar acentuado torna impraticável a determinação dos pontos de separação entre as espécies, variedades e formas indicados por Loesener (1901). No geral, espécimes com o fenótipo que se enquadra em $I$. integerrima ou de I. psammophila se distribuem na Planície Litorânea e na metade inferior das montanhas serranas sendo caracterizados pelos pecíolos mais compridos $(18-45 \mathrm{~mm})$ e lâminas oblongas maiores (7,5-15 cm compr.). Espécimes com o fenótipo que se enquadra em Ilex theezans var. acrodonta Loes. ou Ilex theezans var. typica Loes. ocorrem nos planaltos e na porção alta das montanhas da Serra do Mar sendo caracterizados pelos pecíolos mais curtos (7-20 mm) e lâminas obovadas menores (4-7 cm compr.).

Na flora de São Paulo, Groppo \& Pirani (2002) apontaram a mesma dificuldade para separação entre $I$. integerrima e I. theezans. Na flora de Santa Catarina, Edwin \& Reitz (1967) incluíram o fenótipo de I. integerrima na descrição de I. theezans, embora não tenham discutido se essas espécies constituem uma só (Giberti 1990). No entanto, Edwin \& Reitz (1967) indicaram Prinos serratus Vell. entre os sinônimos de I. theezans. O problema é que Vellozo (1825) apresentou descrições muito sucintas e ilustrações pouco detalhadas para Prinos glaber Vell., Prinos serratus Vell. e Prinos integerrimus Vell., dificultando o apontamento da relação destes com os táxons apresentados por Reissek (1861) e Loesener (1901). Só uma nova revisão desse complexo poderá lançar luz sobre essa questão. Por isso, eu preferi adotar o conceito de Ilex theezans sensu lato no presente trabalho.

\section{Agradecimentos}

Eu agradeço a Bianca K. Canestraro e a Eduardo D. Lozano, pela revisão do texto e sugestões. Também agradeço aos dois revisores anônimos que contribuíram com a análise crítica do manuscrito.

\section{Contribuição do autor}

Marcelo Leandro Brotto: Responsável pela concepção do estudo, coleta de dados, análise, redação, produção de ilustrações e mapas.

\section{Conflitos de interesse}

Não há conflitos de interesse.

\section{Literatura citada}

Alvares, A.C., Stape, J.L., Sentelhas, P.C., Gonçalves, J.L.M. \& Sparovek, G. 2013. Köppen's climate classification map for Brazil. Meteorologische Zeitschrift 22(6): 711-728.

Andrews, S. 1985. A checklist of Aquifoliaceae of Bahia. Rodriguésia 37(63): 34-44.

Brotto, M.L., Vieira, T. \& Santos, E.P. dos. 2007. Flórula do Morro dos Perdidos, Serra de Araçatuba, Paraná, Brasil: Aquifoliaceae. Estudos de Biologia 29(67): 129-135.

Cabral, A., Cardoso, P.H., Menini Neto, L. \& SantosSilva, F. 2018. Aquifoliaceae na Serra Negra, Minas Gerais, Brasil. Rodriguésia 69(2): 805-814.

Cabral, A., Groppo, M., Cardoso, P.H., Menini Neto, L. \& Santos-Silva, F. 2019. Flora do Parque Estadual do Ibitipoca, Minas Gerais, Brasil: Aquifoliaceae. Rodriguésia 70: e03782017.

CRIA. 2020. INCT- Herbário Virtual da Flora e dos Fungos. Centro de Referência em Informação Ambiental. Disponível em http://inct.splink.org.br/ (acesso em 16-IV-2020).

Edwin, G. \& Reitz, P.R. 1967. Aquifoliáceas. In: Reitz, P.R. (ed.). Flora Ilustrada Catarinense, parte I, fasc. Aqui. Itajaí: Herbário Barbosa Rodrigues.

Giberti, G.C. 1990. Ilex theezans, espécie confirmada para nuestra flora. Clave de las espécies argentinas del gênero Ilex (Aquifoliaceae).Boletin de la Sociedad Argentina de Botanica 26(3-4): 159-162.

Groppo, M.\& Pirani, J.R. 2002.Aquifoliaceae. In: Wanderley, M.G.L., Shepherd, G.J., Melhem, T.S., Giulietti, A.M.\& Martins, S.E. (eds.). Flora fanerogâmica do Estado de São Paulo. Instituto de Botânica, São Paulo, 2: 31-37. 
Groppo, M. \& Pirani, J.R. 2005. Flora da Serra do Cipó, Minas Gerais: Aquifoliaceae. Boletim de Botânica da Universidade de São Paulo 23(2): 257-265.

Groppo, M. 2014. Aquifoliaceae. In: Kaehler, M., Goldenberg, R., Labiak, P.H., Ribas, O. dos S., Vieira, A.O.S. \& Hatschbach, G.G.(eds.). Plantas Vasculares do Paraná. Curitiba, PR: Departamento de Botânica.

Groppo, M. 2015. Aquifoliaceae. In: Lista de Espécies da Flora do Brasil. Jardim Botânico do Rio de Janeiro. Disponivel em http://floradobrasil.jbrj.gov.br/jabot/ floradobrasil/FB50 (acesso em 20-I-2020).

IAPT. 2018. Código Internacional de Nomenclatura para algas, fungos e plantas (Código de Sehnzen). Tradução: Bicudo, C.E.M.; Prado, J.; Hirai, R.Y. International Association for Plant Taxonomy. RiMa Editora: São Paulo, Instituto de Botânica.

IBGE. 2020a. PEVS 2019: valor da produção da silvicultura e da extração vegetal cai 2,7\% e fica em R\$ 20 bilhões. Disponível em https://agenciadenoticias.ibge.gov.br/ agencia-sala-de-imprensa/2013-agencia-de-noticias/ releases/29165-pevs-2019-valor-da-producao-dasilvicultura-e-da-extracao-vegetal-cai-2-7-e-fica-emr-20-bilhoes (acesso em 04-X-2021).

IBGE. 2020b. Cidades e Estados: Paraná. Instituto Brasileiro de Geografia e Estatística. Disponível em https://www.ibge.gov.br/cidades-e-estados/pr/.html (acesso em 16-IV-2020).

ITCG. 2009. Formações Fitogeográficas - Estado do Paraná. Mapa, escala 1:2.000.000. Instituto de Terras, Cartografia e Geociências. Disponível em http://www.itcg.pr.gov. br/arquivos/File/Produtos_DGEO/Mapas_ITCG/PDF/ Mapa_Fitogeografico_A3.pdf (acesso em 16-IV-2020).

Koehler, A., Galvão, F. \& Longhi, S.J. 2002. Floresta Ombrófila Densa Altomontana: aspectos florísticos e estruturais de diferentes trechos na Serra do Mar, PR. Ciência Florestal 12(2): 27-39.

Lawrence, G.H.M. 1951. Taxonomy of Vascular Plants. USA, The Macmillan Company, 823.

Loesener, T. 1901. Monographia Aquifoliacearum. Nova Acta Academiae Caesareae Leopoldino-Carolinae Germanicae Naturae Curiosorum 78: 1-567.

Loizeau, P.A. \& Spichiger, R. 1992. Proposition d'une classification des inflorescences d'Ilex L. (Aquifoliaceae). Candollea 47: 97-112.

Loizeau, P.A., Barriera, G., Manen, J.F.\& Broennimann, O. 2005. Towards an understanding of the distribution of Ilex L. (Aquifoliaceae) on a World-wide scale. Biologiske Skrifter 55: 501-520.

Loizeau, P.A., Savolainen, V., Andrews, S., Barriera, G. \& Spichiger, R. 2016. Aquifoliaceae. In: Kadereit, J.W. \& Bittrich, V. (eds.). The families and genera of vascular plants - flowering plants Eudicots. Springer, New York, 14: 31-36.

Maack, R. 2002. Geografia física do estado do Paraná. 3ed. Imprensa Oficial Paraná, Curitiba.

Manen, J.F., Barriera, G., Loizeau, P.A. \& Naciri, Y. 2010. The history of extant Ilex species (Aquifoliaceae): evidence of hybridization within a Miocene radiation. Molecular Phylogenetics and Evolution 57: 961-977.

MINEROPAR. 2001. Atlas Geológico do Estado do Paraná. Minerais do Paraná S/A, Curitiba, 125p. Disponível em http://www.iat.pr.gov.br/Pagina/Atlas-Geologico-doEstado-do-Parana\#(acesso em 16-III-2021).

QGIS.org. QGIS Geographic Information System. QGIS Association. Disponível em https://docs.qgis.org/2.18/ pdf/en/QGIS-2.18-UserGuide-en.pdf (acesso em 16IV-2020).

REFLORA - Herbário Virtual. 2020. Disponível em http://reflora.jbrj.gov.br/reflora/herbarioVirtual/ (acesso em 16-IV-2020).

Reissek, S. 1861. Ilicineae. In: Martius, C.F.P. \& Eichler, A. (eds.) Flora Brasiliensis. Lipsiae apud Frid. Fleischer in comm 11: 37-80.

Ritter, L.M.O., Ribeiro, M.C.\& Moro, R.S. 2010. Floristic composition and phitophysiognomies of Cerrado disjunct remnants in Campos Gerais, PR, Brazil - Southern boundary of the biome. Biota Neotrop. 10(3): 379-414. Disponível em https://www.biotaneotropica. org.br/v10n3/en/abstract?article+bn04010032010 ISSN 1676-0603 (acesso em 11-III-2021).

Roderjan, C.V., Galvão, F., Kuniyoshi, Y.S. \& Hatschbach, G.G. 2002. As unidades fitogeográficas do estado do Paraná, Brasil. Ciência \& Ambiente 13(24): 75-92.

Saint-Hilaire, A. de. 1823. Aperçu d'un Voyage dans l'intérieur du Brésil, la Province Cisplatine et les missions dites du Paraguay (Extrait des Mémoiresdu Muséum d'Histoire Naturelle, 5 anné, t. 9). A. Belin, Paris. Disponível em http://objdigital.bn.br/objdigital2/ acervo_digital/div_obrasraras/or1499043/or1499043. pdf (acesso em 08-II-2020).

Santos, L.B dos. 2016. Sistemática e filogenia de Maytenus Molina (Celastraceae) na região neotropical. Tese de Doutorado, Universidade Estadual Paulista, Instituto de Biociências de Rio Claro, São Paulo.

Scheer, M.B. \& Blum, C.T. 2011. Arboreal diversity of the Atlantic Forest of Southern Brazil: from the beach ridges to the Paraná river. In: O. Grillo, \& G. Venora (eds.). The dynamical processes of biodiversity - Case studies of evolution and spatial distribution. InTech.: 109-134.

Scheer, M.B., Mocochinski, A.Y. \& Roderjan, C.V. 2011. Estrutura arbórea da Floresta Ombrófila Densa Altomontana de serras do Sul do Brasil. Acta Botânica Brasílica 25(4): 735-750.

Thiers, B. 2020. Index Herbariorum: A Global Directory of Public Herbaria and Associated Staff. New York Botanical Garden's Virtual Herbarium. Disponível em http://sweetgum.nybg.org/science/ih/ (acesso em 08-II-2020).

Vellozo, J.M. da C.1825. Florae Fluminensis, seu, Descriptionum plantarum praefectura Fluminensi sponte mascentium liber primus ad systema sexuale concinnatus. Flumine Januario, ex Typographia Nationali. 
Viani, R.A.G. \& Vieira, A.O.S. 2007. Flora arbórea da bacia do rio Tibagi (Paraná, Brasil): Celastrales sensu Cronquist. Acta Botanica Brasílica 21(2): 457-472.

Vieira, R.S., Blum, C.T. \& Roderjan, C.V.2014. Caracterização florística e estrutural de uma Floresta Ombrófila Densa Altomontana na Serra do Capivari, Campina Grande do Sul, Paraná. Floresta 44(4): 565-576.

Warming, E. 1879-1880. Symbolaead floram Brasiliae centralis cognoscendram. Edit Eug. Warming. Particula XXVI. (Cum tab. IV-VI) Araceae; Celastraceae; Ilicineae; Rhamnaceae; Gramineae. Videnskabelige Meddelelser fra den Naturhistoriske Forening i Kjøbenhavn 41-42: 357-386.
Yao, X., Tan, Y.H., Liu, Y.Y., Song, Y., Yang, J.B. \& Corlett, R.T. 2016. Chloroplast genome structure in Ilex (Aquifoliaceae). Scientific Reports 6: 28559.

Ziller, S.R., Rachwal, M.F.G., Curcio, G.R.\& Maschio, W. 1999. Levantamento fitossociológico em formações pioneiras de influência marinha (Restinga) na Fazenda Banestado, município de Paranaguá - PR. In: Congresso e exposição internacional sobre florestas. Curitiba. Forest 99 [resumos]. Rio de Janeiro: BIOSFERA. Disponível em http://ainfo.cnptia.embrapa.br/digital/bitstream/ item/86515/1/Bio1069.pdf (acesso em 16-III-2021).

Recebido: $20 / 01 / 2021$ Aceito: 29/09/2021

Editor Associado: Alain Chautems

\section{Lista de coletores}

Abrão, M.Z. s.n. DVPR 805(9.1), DVPR 923(9.1); Adeneski-Filho, E. 160(4); Aguiar, T.H. 55(4); Albrecht, V.D. s.n. MBM 359504(9.1); Alves, J. s.n. ESA 113083(6), MBM 337992(4); Andrade, P.R. de s.n. MBM 297947(12), MBM 301275(9.1); Antunes, J.A.M. 1(9.1); Ariati, V. 852(9.1), 863(11); Assumpção, M.Z. s.n. FUEL 45137(9.1); Athayde, S.F. 5(9.1), 19(12), 175(6);Augusto-Silva, M. s.n. MBM 397573(9.1); Azoubel, M.L. 119b(9.1); Barbosa, S.Y.K. 1(9.1); Barboza, E. 207(12), 407(4); 529(9.1), 570(9.1), 616(5), 619(5), 656(12), 731(12), 864(5), 1153(12), 1256(4), 2081(3), 2391(5), 3981(3), 4668(9.1); Barddal, M.L. 52(5), s.n. EFC 11462(6); Barros, F. de 2131(1), 2135(1);Becker, F.G. 9(12); Begamasco Neto, L. s.n. HCF 2552(9.1); Benck s.n. FUEL 21059(4); Bernal, A. s.n. HUCP 5012(9.1); Bianchini, E. s.n. MBM 189350(9.1); Bianek, A.E. 208(4), 301(6), 332(12); Bidá, A. 553(12), 584(6), 597(9.1), 670(12); Bizarro, O.M.R. 29(8), 48(8), 51(5), s.n. EFC 12165(12); Blum, C.T. 10-043(12), 10-086(12), 10-108(9.1), 10-123(9.1), 10-125(12), 11-029(4), 11-031(11), 11-032(9.1), 1254(8), 1727(5), 1842(6); Bolson, M. 427(12);Bona, L.P. 801(12); Bonaldi, R.A. 540(12), 564(12), 610(6), 615(10), 630(12), 769(6), 773(12), 787(9.1);Borges, J.P. 31(9.1), 37(9.1), 57(4), 85(4), 86(4), 97(6), 101(9.1), 102(9.1), 103(9.1), 104(9.1), 126(6), 131(4), 158(9.1), 206(6);Borgo, M. 515(12), 752(5), 1873(12), 1906(6), 1928(12); Braga, R. 29(9.1), 30(9.1), 31(6), 33(9.1), 34(9.2), 514(6), 1022(6), 1706(9.1), s.n. HUPG 4839(9.1);Britez, R.M. 2(12), 195(6), 807(9.1), 1009(12), 1036(12), 1228(4), 1285(12), 1297(4), 1317(12), 1369(9.1), 1397(10), 1420(6), 1443(12), 1853(12), 2148(12), 24710(12), 24711(12), 24712(12), 24713(12);Brotto, M.L. 37(11), 54(8), 76(6), 80(9.1), 84(5), 85(8), 119(5), 165(5), 213(9.1), 214(9.1), 263(8), 290(4), 294(11), 302(12), 316(11), 317(12), 325(9.1), 330(5), 495(5), 514(9.1), 600(11), 952(11), 957(3), 1318(11), 1382(8), 1383(9.1), 1420(12), 1585(11), 1611(5), 1824(11), 2094(12), 2096(11), 2264(11), 2528(6), 2530(8), 2546(4), 2577(8), 3173(5), 3177(3), 3704(9.1), 3705(12), 3706(7), 4000(7), 4001(12), 4023(12), 4024(7);Bruniera, C.P. 343(12); Bueno, J. 7(9.1); Buturi, C.V. 67(8), 68(12); Caliari, C.P. 2210(9.1), 2212(9.1);Canestraro, B.K. 274(4);Carmo, M.R.B. do 46(2), 360(2), 489(12), 688(2), 914(2), 651(3), 822(3); Carneiro, D. s.n. FUEL 11646(6);Carneiro, J. 136(1), 144(1), 472(9.1); Carneiro, J.S. 430(9.1); s.n. FUEL 33322(9.1); Carpanezzi, A.A. 132(12); Carvalho, P. 22(6), 31(12), 35(9.1);Carvalho, P.E. 24(6), 115(4), 239(4), 291(4); Cassanello, A.M.L. s.n. UPCB 19029(4);Cavalheiro, A.L. 1(6), 29(9.1), s.n. FUEL 22368(12); Cavassani, A. s.n. MBM 299914(11); Caxambu, M.G. 132(9.1), 146(9.1), 1282(6), 1462(9.1), 1837(12), 2075(11), 2483(12), 2810(12), 2829(9.1), 3496(12), 3619(9.1), 3635(6), 3673(9.1), 4328(12), 4337(10), 4366(9.1), 4394(12), 4468(6), 4810(6), 5610(9.1), 5611(6), 5612(12), 5675(2), 7600(9.1), 7926(3), 8072(3); Ceccatto, G.K. 54(6); Ceolin, L. 389(12); Cervi, A.C. 2021(6), 2042(12), 2207(5), 2277(12), 2865(12), 2974(5), 2800(3), 2810(9.1), 3010(5), 3014(5), 3243(12), 3600(3), 3671(12), 3806(2), 6322(3), 6366(3), 6532(12), 6569(12), 6585(5), 6859(3), 6869(3), 6886(8), 6915(12), 7058(3), 8217(9.1), 8545(12), 9951(12), s.n. UPCB 22654(9.1); Cervigne, N.S. 42440(9.1); Chagas e Silva, F. 1568(4), 1659(6), 1712(4), 1853(5), 1862(3), 2039(6), 2040(3), 2115(2), s.n. FUEL 12590(9.1), FUEL 17315(6), FUEL 17382(4);Chaves, H. 5(9.1); Chevalier, A. s.n. P 3616829(9.1), P 3616833(9.1), P 4423047(9.1); Cielo-Filho, R. 1540(9.1), 1600(9.1), 1610(9.1); Coelho, E.C. s.n. HCF 4079(9.1); Colli, S. s.n. FUEL 7654(4); Conceição, L.H.S.M. 10(9.1); Cordeiro, J. 123(9.1), 270(5), 386(8), 454(7), 690(6), 1119(2), 1189(12), 1206(6), 1354(8), 1382(5), 1486(10), 1506(6), 1624(2), 1769(8), 1786(12), 2083(8), 2109(9.1), 2111(12), 4704(2); Cordeiro, Juliano 248(4);Correia, D. s.n. HUCP 5064(9.1); Costa Filho, S.V.S. 7(6), 8(12); Costa, E.F. 17(12); Cotarelli, V.M. 86(9.1), 163(12), 288(9.1); Cruz, J. 16(12); Cruz, J. da 94(9.1), 120(9.1); Cruz, J.M. 20(12), 217(8), 281(8); Dala Rosa, S. 1(12), 28(12), 43(12), 63(8), 71(12); Dall'Agnol, R.F. 138(3); De Pauli, A.C. s.n. UPCB 15708(9.1); Dias, M.C. 485(9.1), s.n. FUEL 11820(4), FUEL 7614(6); Dieniffer s.n. DVPR 1173(9.1); Dittrich, V.A.O. 118(6), 244(9.1); Dombrowski, L.T. 136(6), 987(6), 1247(9.1), 4684(12), 5000(9.1), 5018(12), 6131(6), 10087(6), 11966(5), 12091(9.2), 12281(6), 12293(6), 12674(9.1), 12821(9.1), 13098(10), 13099(6), 13214(6), 13244(9.1), 13364(6), s.n. MBM 179594(6), MBM 179621(12); Duarte, E. 178(9.1), 238(9.1); Dunaiski Jr., A. 304(6), 522(5), 629(8), 814(8), 949(6), 1477(6), 1519(6), 1625(8), 1682(8), 1788(9.1), 2253(12), 2731(8), 3489(11), 3975(9.1), 4103(4), 4306(12), s.n. MBM 390946(6); Dusén, P.K. 6935(9.2), 7076(9.1), 7487(6), 7504(12), 7851(12), 8108(6), 8110(12), 8263(10), 8646(10), 8650(6), 8728(12), 8859(12), 
9259(4), 11063(12), 11076(6), 11628(4), 12137(12), 13750(6), 13884(4), 14634(6), 15478(6), 15543(12), 15892(12), 16722(12), 17097(4), 17221(12), s.n. NY 497014(8), NY 497140(5);Engels, M.E. 898(3), 1633(9.1), 1688(12), 1778(12); Escher, A.R. 14(9.1), 18(9.1); Espindola, A.B. 10(3); Estevan, D.A. 6(3), 136(9.1), 219(12), 395(12), 401(3), 1402(12), 1910(6), 1919(12); Fadelli, L. s.n. FUEL 24006(3); Fagundes-Filho, C.A. 46(5); Felitto, G. 287(12), 463(3); Fernandes, H.M. 42(12), 56(8);Ferreira Jr., M. 341(3); Ferreira, B. s.n. DVPR 670(9.1); Ferreira, G.M. 205(9.1); Ferreira, J.A. s.n. DVPR 787(12), FUEL 24839(4); Ferreira, P.C. 84(8), 127(10), 138(12);Filipaki, S.A. s.n. UPCB 33101(6), UPCB 33097(9.1); Finotti 2(12); Fonseca, E.P. s.n. FUEL 12589(12), FUEL 17322(12); Fontana, A.C. 345(9.1); Forzza, R.C. 7294(12); Francisco, E.M. 119(4), 129(4), s.n. FUEL 21844(12), FUEL 21845(9.1), FUEL 21851(3), FUEL 22306(4), FUEL 22354(6), FUEL 22367(12), FUEL 22369(12), FUEL 22370(9.1), FUEL 23285(12), FUEL 24822(3), FUEL 24829(3), FUEL 24837(12), FUEL 24838(12), FUEL 26024(12), FUEL 26936(12), FUEL 26938(12); Francisco, L.A. s.n. FUEL 14552(2); Franzoi, P.A.P.12(12), 22(12), 28(12);Galvão, F. 52(12), 53(12); Gasper, A.L. 346(9.1); Gasperin, A. 11(9.1); Gatti, G. 56(12), 97(12), 104(11), 106(12), 328(9.1), s.n. MBM 275319(6); Geraldino, H.C.L. 123(12), 191(6); Gilberti, G.C. 265(12), 266(6), 267(11), 268(12), 269(8), 270(8), 271(5), 275(9.1), 279(6), 280(6), 283(12), 286(12), 287(12); Gurgel, L. 79(9.1), 80(12), 86(9.1), 1614(9.1), 14982(9.1), 16039(9.1), 16089(6), 16090(12), 16092(12), 16095(6), 16096(12), 16097(6), 16100(6), 16114(9.1), 16126(12), 16129(12), 16130(9.1), 16135(12), 16136(6), 16138(6), 16144(9.2), 16145(9.2), 16202(12), 16223(6), 18578(9.1), 18579(9.1), 18580(9.1), 18582(9.1), 18583(9.1), 18584(9.1), 18585(9.1), 18586(9.1), 18589(9.1), s.n. MBM 342642(6), RB 58062(9.1), RB 58064(4), RB 58066(9.1), RB 111660(9.1), RB 111663(9.2), RB 111664(9.1), RB111665(9.1), RB 136254(9.1), RB 136263(12); RB 136264(4), RB 136265(4), RB 152614(4), RB 152620(4);Hatschbach, G. 491(12), 508(8), 805(9.1), 1578(12), 1602(12), 1632(5), 2052(8), 2083(11), 2088(12), 2102(10), 2678(12), 2858(6), 2950(11), 4002(6), 4137(8), 4174(12), 4300(10), 4301(6), 4302(6), 5069(2), 5081(12), 5110(5), 5146(12), 5154(6), 7391(12), 7550(12), 8442(8), 10578(6), 11075(12), 11891(6), 11918(4), 12052(10), 12145(3), 12360(9.1), 12457(6), 12979(9.1), 12992(9.1), 13044(3), 13054(9.2), 13071(12), 13118(8), 13129(12), 13484(12), 13670(4), 13699(6), 13813(9.1), 13841(9.1), 13863(9.1), 14256(3), 14558(5), 14737(8), 14841(12), 15073(8), 15120(12), 15222(12), 15304(6), 15395(4), 15421(6), 15780(1), 16084(8), 16089(9.1), 16344(9.1), 16707(8), 16742(12), 16947(3), 17318(8), 17356(2), 17408(12), 17547(6), 17672(6), 17724(4), 17813(9.1), 17921(10), 17932(6), 18062(12), 18213(12), 18297(12), 18478(12), 18628(9.1), 18959(3), 19062(12), 19514(8), 19905(12), 19965(5), 19999(3), 20052(9.2), 20371(4), 20442(6), 20941(8), 20943(11), 21348(11), 21411(10), 22351(12), 22359(9.1), 22507(12), 22568(6), 22663(12), 22729(9.1), 22734(9.1), 22785(12), 22837(8), 22838(12), 22858(6), 22945(6), 23235(4), 23395(5), 24206(8), 25383(8), 25637(6), 25642(12), 25752(12), 26344(9.1), 26389(6), 26443(9.1), 26509(9.1), 26537(12), 26589(3), 26699(1), 26884(6), 26895(9.1), 27073(12), 28114(5), 28155(4), 28259(6), 28630(12), 29283(8), 29709(9.1), 30642(9.1), 30748(6), 30764(9.1), 30780(9.1), 30782(4), 30795(6), 31026(11), 32155(5), 32323(6), 32837(9.1), 32844(12), 34517(9.1), 34907(6), 34914(8), 35210(9.1), 35513(12), 37107(3), 37317(3), 37346(12), 38078(12), 38079(12), 39751(9.1), 38842(12), 39157(12), 39878(8), 40023(12), 40181(6), 40257(8), 40326(12), 40459(12), 41080(12), 41159(12), 41741(6), 41743(12), 42179(4), 42480(8), 43266(9.1), 43351(3), 43447(4), 43897(12), 44317(12), 44365(9.2), 44450(11), 44611(4), 44865(12), 44924(10), 45767(10), 46054(9.1), 48576(6), 50804(6), 50805(4), 50806(8), 50836(12), 50876(6), 50880(12), 51484(12), 51486(6), 52533(11), 53592(6), 53596(12), 54805(6), 54908(6), 58205(12), 61222(5), 61223(12), 61224(8), 61225(12), 64522(12), 68673(9.1), 68725(4), 68743(9.1), 68744(12), 68745(9.1), 68756(9.1), 68793(3), 68799(3), 68817(11), 68832(12), 68837(12), 68842(12), 68845(6), 68846(12), 69817(12), 69887(11), 72734(6); Heemann, A.C.W. 3(9.1); Hertel, R. s.n. MBM 179603(4); Hoehne, F.C. 23296(12); Imaguire, N. 309(6), 310(12), 386(9.1), 753(9.1), 1054(9.1), 2571(12), 2664(12), 2963(12), 3139(12), 3302(12), 3395(12), 5007(9.1), 5258(6), 5391(4); Jablonski, L.F. s.n. HUCP 5088(9.1); Jaster, C. s.n. UPCB 41124(6), UPCB 41125(12), UPCB 41148(10), UPCB 41149(6); Jenheski, C. s.n. MBM 394469(9.1); Jesus, C.S. 48(9.1), 49(9.1);Jönsson, G. 1312a(9.2), 1341a(2); Kasper, A. s.n. EFC 51(4);Klein, R.M. 4590(6); Koczicki, C. 47(6), 70(8), 86(12), 264(9.1), $266(12)$; Koehler, A. 179(11), 180(8); Kokubo, N.T. 10(12); Kozera, C. 517(12), 1827(1), 1828(1), 3324(12);Krieger, L. 11039(6), 15494(9.2), 11025(10), 11030(10), 11311(12), 20045(9.1);Kuhlmann, J.G. s.n. RB 150717(4); Kummrow, R. 694(12), 728(12), 756(12), 972(6), 986(6), 978(5), 1002(12), 2081(11), 2380(9.1), 2501(12), 2637(12), 2678(11), 2843(5), 3087(8), 3089(12), 3137(3), 3368(8);Kuniyoshi, Y.S. 564(7), 3974(12), 4074(9.1), 4080(6), 4082(12), 4083(9.1), 4090(12), 4113(6), 4340(9.1), 4375(9.1), 4390(9.1), 4546(9.1), 4610(4), 4715(8), 4797(12), 4828(7), 4922(9.1), 5017(12), 5018A(7), 5018B(8), 5025(12), 5037(7), 5039(7), 5040(6), 5041(8), 5043(8), 5044(8), 5045(9.1), 5046(8), 5047(7), 5048(7), 5052(12), 5053(9.1), 5056(9.1), 5057(12), 5059(12), 5060(9.1), 5061(12), 5067(9.1), 5069(9.1), 5074(9.1), 5075(9.1), 5076(9.1), 5077(9.1), 5078(9.1), 5080(9.1), 5081(9.1), 5082(9.1), 5084(9.1), 5085(9.1), 5089(9.1), 5090(8), 5091(12), 5092(12), 5094(6), 5095(8), 5096(8), 5097(8), 5098(8), 5101(8), 5102(6), 5109(9.1), 5110(10), 5111(6), 5112(12), 5125(9.1), 5140(9.1), 5141(9.1), 5142(12), 5147(9.1), 5148(9.1), 5149(9.1), 5150(10), 5203(12), 5226(12), 5237(6), 5240(6), 5447(12), 5450(4), 5524(12), 5550(9.1), 5552(8), 5553(12), 5554(9.1), 5555(9.1), 5556(12), 5557(10), 5558(12), 5580(6), 5696(8), 5985(12), 6124(6); Labiak, P.H. 1941(7), 2006(9.1);Lacerda, A. 133(12), 141(6), 193(9.1), 255(6), 256(11), 270(12), s.n. MBM 365915(9.1), MBM 365916(9.1); Landrum, L.R. 2369(8), 2375(6), 3888(6); Leite, P.F. 68(9.1);Lenchinski, L.F. s.n. UPCB 85402(9.1), UPCB85403(9.1);Lenz, V.L. 1(9.1); Liebsch, D. 618(12), 968(6), 1020(4), 1304(12), 1306(12), 1326(12); Lima, A. 69(9.1); Lima, R.X. 106(12), 355(12); Lindeman, J.C. 873(12), 997(4), 1152(12), 1199(4), 1217(12), 1906(12), 1916(6), 1969(3), 2890(4), 2898(9.1), 3051(5), 3369(6), 3405(1), 3803(12), 4702(12), 4703(12), 4783(12), 4912(9.1), 4934B(6), 4954(4), 5024(12), s.n. MBM 7464(12), MBM 7471(3); Loughi, S. s.n. MBM 66450(6), MBM 66451(4); Lozano, E.D. 52(8), 204(8), 413(8), 1365(5), 1659(3), 1773(3); Marinero, F. 89(12), 128(12), 253(3); Marques, M.C.M. s.n. UPCB 40838(12); Martins, B.R. 16(2);Martins, E. 5(9.1), 33(12), s.n. FUEL 49776(12), FUEL 49794(9.1); Maschio, W. 32(6), 39(7); Mattjie, G.E. s.n. DVPR 663(9.1); Medri, M.E. s.n. FUEL 8005(9.1), FUEL 17318(9.1); Meireles, L.D. 1425(12), 1436(10); Melo, E. 2501(6), 2508(8); Meyer, 
F.S. 609(8); Milaneze-Gutierre, M.A. 31(12), 688(9.1); Miranda, B.P. s.n. EFC 17670(8), EFC 17703(8); Mocochinski, A.Y. 30(12), 32(8), 33(5); Moreira Filho, H. 299(6), 432(3); Moro, R.S. 357(5), 598(2), 973(5); Moscheta, I.S. s.n. MBM 194204(9.1); Motizuki, K. s.n. EFC 1932(6); Motta, J.T. 595(9.1), 644(7), 846(12), 849(4), 1093(12), 1614(6), 1844(3), 1914(12), 4388(12); Müller 44(9.1), 53(12), 239(12);Müller, C.A.S. s.n. DVPR 4794(9.1); Muniz, J.R.S. s.n. EFC 50(9.1); Neves, R.C.P. 87(9.1); Nicobeck, V. 505(12); Nicolau, S.A. 1086(4); Nogarolli, R.L. 45(9.1); Nogueira, A.C. 10(9.1), 13(9.1);Nowacki, M.J. s.n. MBM 4077(9.1), MBM 4078(9.1), MBM 80522(9.1);Oliveira, A. 10(3); Oliveira, A.A. 3402(12), 4355(12); Oliveira, P.I. 101(9.1), 682(12), 786(6), 1013(9.1); Pacheco, G.B.S. 51(6);Paciornik, E.F. 308(7); Paiva, M.R.C. s.n. FUEL 26939(9.1);Paro, F.E. 72(12); Pavão, O.C. 16(4), s.n. FUEL 24831(9.1), FUEL 24833(4), FUEL 24848(9.1), FUEL 25743(12), FUEL 26006(12), FUEL 26023(12), FUEL 27325(9.1), FUEL 27687(4), FUEL 27791(12), FUEL 30570(4), FUEL 45584(12);Pegoraro, A. 132(6); Pereira, B. s.n. DVPR 2601(12);Pereira, E. 7966(6);Picheth, J.A.T.F. s.n. EFC 6635(9.1); Pinto, R.M.C. s.n. HUPG 19414(9.1);Pirani, J.R. 574(4); Polak, L.P. s.n. HUPG 5127(9.1); Poliquesi, C.B. 30(4), 204(8), 215(5), 219(5), 625(2); Portela, E. s.n. HUCP 5172(12); Portes, M.C. 8(11), 179(5), 182(8); Possette, R.F.S. 308(6), 315(12), 320(6), MBM 298188(9.1); Prado, J. 413(6); Prat Kricun, S.D. 93(6), 104(6), s.n. MBM 261950(12); Quadros, C.G. s.n. DVPR 662 (9.1); Rabello, F.J. 14(12);Reginato, M. 327(11), 385(7), 420(11), 477(9.1), 561(2), 572(3), 602(9.1); Reiss, R. 93(9.1); Reitz, R. 17648(12), 17936(5); Ribas, O.S. 11(6), 226(12), 310(12), 311(6), 323(12), 326(12), 617(8), 697(12), 808(10), 872(12), 948(8), 960(6), 3162(12), 3180(2), 5741(12), 5806(12), 5864(5), 5874(8), 6621(9.1), 7025(7), 7093(9.1), 7182(5), 8368(12), 8580(12);Ribeiro, A. 4(8); Ribeiro, C.L. 2(4), 32(12), 102(3), 105(8), 154(3); Ristow, R. 741(5), 742(5); Rocha Filho, J.A. 528(9.1); Roderjan, C.V. 32(9.1), 35(6), 37(9.1), 75(12), 99(12), 230(6), 325(6), 335(4), 374(12), 407(9.1), 495(6), 582(12), 669(8), 812(12), 959(8), 965(5), 976(5), 982(12), 1042(8), 1081(9.1), 1082(9.1), 1083(11), 1106(6), 1109(5), 1112(12), 1114(9.1), 1115(8), 1116(11), 1280(6), 1365(8), 1382(12), 1402(3), 1422(5), 1431(5), 1508(8), 1649(6), 1712(9.1), 1798(12);Rodrigues, W.A. 11313(6), 11322(6);Roher, D. s.n. MBM 397351 (5);Romão, G.O. 1587(12), 1655(5); Rosa, R. s.n. FUEL 3727(12); Rossetto, E.F.S. 196(9.1); Rotta, E. 18(12), 94(9.1), 98(6), 156(6), 166(6), s.n. MBM 65698(9.1), MBM 65704(6); Royer, C.A. 8(6); Sá, K.L.V.R. de 193(3), 346(12), 353(9.1), 410(12); Saint-Hilaire, A. C2-1474(6), C2-1631(9.1); Sakuragui, C.M. 1221(6); Salviani, E.R. 277(6); Santos, E.P. 150(9.1), 402(8), 540(12), 593(11), 607(8), 632(6), 640(6), 772(11), 816(8), 853(8), 1040(9.1), 1069(8), 1073(5), 1140(12), 1143(7);:Scheer, M. 56(5), 282(5), 374(8), 375(5), 405(9.1); Schiesinsky, D. 25(9.2), 26(5), 149(12), 150(9.2), s.n. MBM 338233(9.1); Schimelpfeng, L.C. s.n. EFC 1692(6), MBM 118905(12); Schwacke, C.A.W. 239(6), 1026(9.1), 2467(9.1), 2468(9.1), 2470(6), 2471(12), 2474(6), 2475(4), s.n. ALCB 11631(6); Segalla, S. s.n. DVPR 775(9.1);Sellow, F.2032/2080(9.1), 4633(6), 4683(6), 4242/4756(9.2), 4952(7); Selusniaki, M. 1316(12), 1382(8), 2341(5), 2530(2), 2589(5), 2772(5), s.n. MBM 378422(4); Sem coletor RB 8714(6); Silva, A.R. 125(9.1), s.n. HUPG 21283(2); Silva, J.M. 190(12), 302(6), 496(12), 511(3), 517(11), 519(5), 556(6), 566(6), 614(12), 657(12), 689(12), 690(6), 727(2), 791(6), 799(12), 803(8), 805(5), 808(6), 810(12), 815(6), 817(12), 818(12), 823(4), 907(12), 918(9.1), 923(4), 926(6), 929(6), 934A(3), 934B(4), 936(6), 937(12), 939(4), 940(12), 960(12), 961(9.1), 964(3), 990(6), 1017(7), 1059(12), 1312(7), 1320(12), 1321(6), 1403(7), 1445(6), 1495(8), 1529(12), 1539(2), 1777(12), 1979(7), 2020(7), 2036(12), 2615(8), 2623(12), 2648(5), 2705(12), 3100(7), 3104(4), 3250(11), 3253(5), 3340(4), 3838(2), 3866((12), 3950(5), 3966(8), 4190(12), 4212(4), 4446(6), 4541(11), 4642(12), 4782(8), 6111(12), 6131(6), 6166(4), 7078(12), 7105B(3), 7156(3), 7575(12), 8153(2), 8406(12), 8454(12), 8605(12), 8631(9.1), 8658(12), 9263(12), 9510(2), 9528(12), 9542(9.1), 9602(6), 9632(12), 9708(6), 9968(12), 9987(9.1); Silva, S.M. 35(6), 38(6), 90(6), 133(6), 154(6), 807(9.1), 842(12), 915(12), 1052(12), 1496(12), 1631(12), 1658(6), s.n. FUEL 13143(12), FUEL 13331(12), FUEL 17321(4), MBM 110139(6), MBM 110200(6), MBM 110202(6), MBM111256(9.1), MBM111257(12), MBM 202418(12), MBM 202419(10), UPCB 24481(10), UPCB 27550(10); Silveira, N. 1862(7); Siqueira, E.L. 112(9.1), 371(9.1), 1724(6), 2062(6), 2829(3), 2425(6), 6957(9.1); Smith, L.B. 14623(5), 145334(3);Snak, C. 63(9.1), 85(9.1), 368(12), 383(12); Soares, A. 31(7), 132(8), 263(6); Soares-Silva, L.H. 285(4); Sonehara, J. 3(10), 120(12); Souza, A.M. s.n. ESA 36754(7); Souza, D. s.n. DVPR 1719(9.1); Souza, I. 361(8), s.n. EFC 15969(4); Souza, L.R.M. s.n. FUEL 20118(6), FUEL 27237(12);Souza, M.K.F. s.n. UPCB 43228(12); Souza, S.M. s.n. FUEL 9097(12); Souza, W.S. 356(12), 720(6), 1533(12); Stange Jr., E. 54(12), 55(12), 56(8), 72(8);Stellfeld, C. 1535(12), 1694(12), 3050(6); Temponi, L.G. 744(12), 1091(9.1);Tessmann, G. 1246(6), 1272(10), 2678(9.1), 2736(4), 2779(9.1), 3582(6), 3597(4), 3791(9.1), 8093(12); s.n. MBM 270268(9.1);Tiepolo, G. 55(12), 75(12), 208(7), 501(6), 565(6); Tramujas, A.P. 168(5), 575(11), 620(11), 705(8); Varotti, R.J.H. 3(12);Velasco, S.J.E. s.n. EFC 13452(12), EFC 13455(6);Vellozo, L.G.C. s.n. MBM 4079(9.1); Viani, R.A.G. 1(12), 24(12), 25(12), 32(9.1), 33(12), 34(9.1), 39(9.1), 40(9.1), 41(3); Vicentini, A. 98(12), 112(9.1), 898(12); Vieira, A.O.S. 348(12), 7613(12), s.n. FUEL 11721(4); Vieira, C.L. 112(5); Vieira, R.S. 45(12), 47(5), 69(8), 73(8), 86(12), 114(12), 137(12), 163(8), 181(5), 199(5), 205(8), 246(5), 271(5), 286(5), 302(8), 340(10), 341(12), 385(5), 386A(5), 386B(8), 568(10), 569(10), 608(10), 692(12), 753(12);Voloschen, T.D. 11(9.1); Völtz, R.R. 71(8), 438(10), 675(9.1), 678(11), 999(6), 1577(5), 1817(3), 1956(6);Wasum, R. 2487(9.1), 3188(6), 3285(9.1), 3927(12); Weir, J. 329(5); Witt, N.E.P.M. s.n. MBM 340156(10);Yasumuto, Y. s.n. MBM 239718(3);Zeglin, G. s.n. MBM 293110(6), MBM 293111(12);Ziller, S.R. 22(6), 63(6), 99(10), 102(12), 278(12), 288(6), 542(12), 573(12), 598(12), 610(6), 611(10), 628(12), 642(12), 633(10), 677(12), 692(6), 712(10), 717(12), 743(6), 758(10), 969(6), 1157(1), 1186(1), 1696(12), 1873(3), 1940(9.1). 